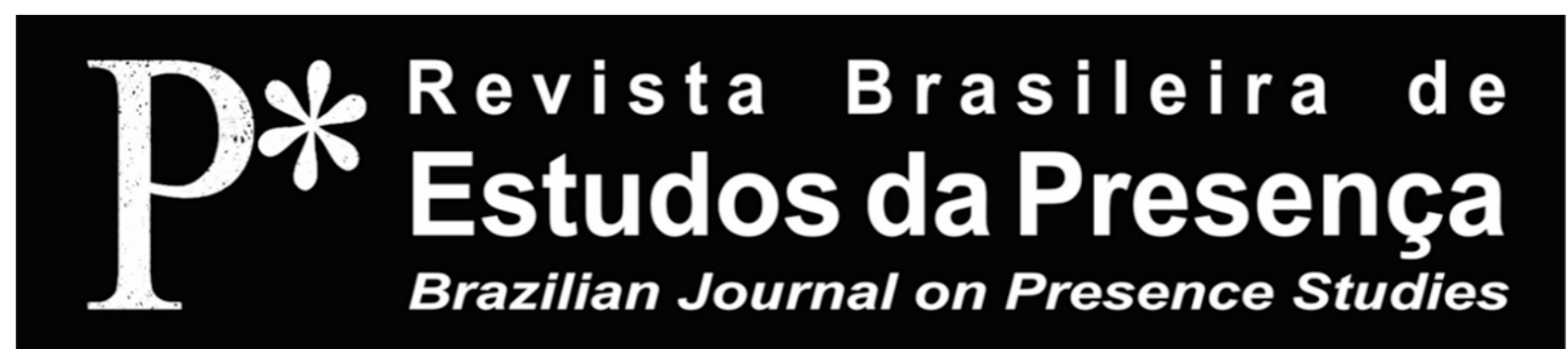

PROCESSOS DE CRIAÇÃO

E-ISSN 2237-2660

\title{
Inter Faces processos de criação para performance com Realidade Aumentada
}

Régis Costa de Oliveira' Mónica Mendes"

Anselmo Cardoso de Paiva ${ }^{\text {III }}$

'Instituto Federal de Educação, Ciência e Tecnologia do Maranhão - IFMA, São Luís/MA, Brasil "ITI/LARSyS e Faculdade de Belas-Artes da Universidade de Lisboa - FBAUL, Lisboa, Portugal

"'Universidade Federal do Maranhão - UFMA, São Luís/MA, Brasil

RESUMO - Inter Faces: processos de criaçáo para performance com Realidade Aumentada - Tendo como locus o uso poético da Realidade Aumentada, neste artigo são apresentadas articulaçóes entre a performance e a tecnologia da Realidade Aumentada com conteúdos digitais autorreferenciais coadunados na proposta artística ativista Inter Faces. Para a reflexão em torno dos processos de criação, é feita a confrontação com os trabalhos artísticos body e Parade to Hope. Pretende-se, com esta análise, apresentar os desafios e as soluçóes encontradas durante o processo de criaçáo de Inter Faces, de modo a contribuir para o debate sobre a expansão, popularização e poetização da Realidade Aumentada na performance.

Palavras-chave: Processos de Criaçáo. Realidade Aumentada. Performance. Autorretrato. Territórios Híbridos.

ABSTRACT - Inter Faces: creation processes for artistic performance enhanced by augmented reality - In view of the poetic use of augmented reality, this article presents links between performance and augmented reality technology with self-referenced digital content, supported by the activist artistic proposal Inter Faces. For a reflection on creative processes, the artistic works body and Parade to Hope are compared. With this analysis we intend to present the challenges and solutions found during the creation process of Inter Faces, seeking to contribute to the debate on the expansion, popularization and poetization of augmented reality in performance.

Keywords: Creation Processes. Augmented Reality. Performance. Self-portrait. Hybrid Territories.

RÉSUMÉ - Inter Faces: processus de création pour la performance avec la Réalité Augmentée - Ayant l'utilisation poétique de la réalité augmentée comme locus, cet article présente des articulations entre la performance et la technologie de la réalité augmentée avec un contenu numérique auto-référencé soutenu par la proposition artistique activiste Inter Faces. Pour une réflexion sur les processus créatifs, on fait la confrontation avec les oeuvres artistiques body et Parade to Hope. On prévu, avec cette analyse, de présenter les défis et les solutions trouvés au cours du processus de création de la recherche Inter Faces, afin de contribuer au débat sur l'expansion, la vulgarisation et la poétisation de la réalité augmentée en performance. Mots-clés: Processus de Création. Réalité Augmentée. Performance. Autoportrait. Territoires Hybrides. 


\section{Introduçáo}

As inovaçôes tecnológicas processadas nas duas últimas décadas possibilitaram à sociedade contemporânea a utilização dos dispositivos móveis (smartphones e tablets) para as mais diferentes funçóes, tais como o acesso à internet e proporcionar experiências com a tecnologia da Realidade Aumentada (RA). A RA é hoje uma ferramenta acessível e o seu uso apresenta um crescimento exponencial. A indústria, o comércio, o setor do entretenimento e o campo da arte vêm explorando as possibilidades dessa tecnologia, em parte motivados pela sua popularização, em parte pela relação de dependência que a sociedade contemporânea mantém com os dispositivos móveis.

A tecnologia da RA, independentemente do campo em que a sua aplicaçáo ocorra, exige a intermediação de algum recurso tecnológico para a visualizaçáo dos conteúdos digitais, sendo o ecrã dos dispositivos móveis o mais usual. No concernente ao campo artístico, as experiências que incorporam a RA aos processos de criaçáo utilizam, além dos smartphones e tablets, projetores multimídia como recursos para permitir ao público a apreciaçáo das informaçóes digitais sobrepostas aos trabalhos artísticos. Destarte, os experimentos que empregam a RA aos processos de criação artística vêm privilegiando os suportes e espaços artísticos tradicionais, o que pode configurar um desafio para as poéticas contemporâneas marcadas pelos signos da hibridização, da efemeridade e da desterritorialização, como a performance. Portanto, uma proposta de açáo performática que contemple a tecnologia da RA em dispositivos móveis apresentará questionamentos tanto técnicos quanto conceituais. Como articular conteúdos digitais a partir da tecnologia da RA em dispositivos móveis com o espaço e o corpo performáticos, garantindo uma simbiose que evidencie e potencialize as dimensóes autorreferencial, conceitual e ativista da performance?

Partindo do questionamento acima, neste artigo pretende-se investigar os processos de criaçáo - aqui compreendido como o conjunto de procedimentos, etapas e atividades realizadas nos planos cognitivo e comportamental, para a obtenção de um produto ou obra visual (Santos, 2004) - implicados na investigaçáo baseada na prática (Candy; Edmonds, 2018) em desenvolvimento pelos autores. Intitulada Inter Faces entre o Autorretrato e a Performatividade no Continuum da Realidade, a investigaçáo articula a RA, o au- 
torretrato e a performance com foco no processo de poetização da tecnologia. Recorrendo a metodologias qualitativas, esse processo inclui a análise de duas experiências artísticas que se arrogaram da RA para a sobreposiçáo de conteúdos digitais no corpo e no espaço: a performance body, de Camila Hamdan (2008) e o trabalho de ativismo em RA Parade to Hope, de Mark Skwarek (2011). Objetiva-se, com tal análise, identificar as potencialidades expressivas, simbólicas e estéticas presentes no recurso artístico da tecnologia da RA em trabalhos performáticos e de intervenção urbana. Pretende-se igualmente vislumbrar novas possibilidades poéticas obtidas tanto a partir da subversáo da ferramenta, quanto do processo de retroalimentação da obra com a interação do público, pois "[...] a arte que se faz com tecnologias interativas tem como pressupostos básicos a mutabilidade, a conectividade, a não-linearidade, a efemeridade, a colaboração" (Domingues, 1997, p. 19).

Inicialmente, são definidos os conceitos de Realidade Virtual (RV), Realidade Aumentada (RA) e Realidade Mista (RM), possibilitando a sua posterior inserção no território que investiga a relação entre o fazer artístico e as tecnologias digitais. Estes primeiros passos sáo necessários para o avançar da caminhada, pois sedimentam o terreno a ser ocupado pelos trabalhos artísticos em RA body (2008) e Parade to Hope (2011), cujos processos de criação são analisados para a identificação dos procedimentos, abordagens conceituais e ferramentas adotadas em cada projeto. $\mathrm{O}$ mapeamento e a comparação entre os processos de criação de body (2008) e Parade to Hope (2011) são utilizados como referência para a análise do processo de criação das açóes performáticas realizadas no contexto da investigação Inter Faces, ações registradas por intermédio de documentos fotográficos, videográficos, relatórios descritivos e site na internet ${ }^{1}$. Esta análise comparativa tem por objetivo buscar as aproximaçóes e distanciamentos entre os processos de criação que partilham a mesma tecnologia, focando especial atenção nos desafios inerentes à poetização da ferramenta da RA em diálogo com a linguagem da performance. Procura-se também permitir que o registro e a publicização do processo de criação de Inter Faces constitua material de consulta para os que procuram na RA possibilidades criativas. 


\section{O Tangível e o Pixel: diálogos possíveis}

A história das imagens técnicas é marcada por transformações. Contudo, foi nos séculos XIX, XX e nos primeiros anos do século XXI que se presenciou e presenciam inovaçóes que impulsionam o processo de criação e veiculação de imagens, tais como a fotografia, o cinema e o vídeo e a substituição das mídias em formato analógico pelo formato digital, resultando em novos paradigmas e novos padróes de comportamento. A digitalização das mídias levou à necessidade crescente do uso do ecrã para intermediar a experiência visual e, por extensão, o processo de fruição de imagens, pois “[...] parece, portanto, indiscutível que vivamos, hoje como nunca antes, imersos em ecrãs, convocando-os ou sendo por eles convocados a todo o momento" (Almeida, 2012, p. 15).

Além do emprego de dispositivos para a apreciação visual, a imagem passou a habitar novas realidades desenvolvidas para a criação e fruição de conteúdos visuais em ambientes virtuais, sendo elas a RV e a RA, ambas integrando o território abrangido pela RM. $\mathrm{O}$ espaço de conceituação compreendido pela RV reúne dois termos cujas definiçóes podem apresentar uma relação contraditória:

O termo realidade virtual (RV) é comumente usado pela mídia popular para descrever mundos imaginários que existem apenas em computadores e em nossas mentes. No entanto, vamos definir com mais precisão o termo. Sherman e Craig [2003] apontam em seu livro Understanding Virtual Reality que o Novo Dicionário Universal Não-Integrado de Webster [1989] define virtual como 'sendo em essência ou efeito, mas não de fato' e realidade como 'o estado ou a qualidade de ser real. Algo que existe independentemente das ideias a respeito. Algo que constitui uma coisa real ou distinta de algo que é meramente aparente'. Assim, realidade virtual é um termo que se contradiz - um oxímoro! (Jerald, 2016, p. 9, tradução nossa).

Apesar do oxímoro formado pelo emprego das palavras realidade e virtual, o termo resultante dessa combinação (RV) é empregado para designar "[...] um ambiente digital gerado por computador que pode ser experimentado e interagido como se esse ambiente fosse real" (Jerald, 2016, p. 9, traduçáo nossa). Dessa forma, o observador é literalmente transportado para o universo da imagem, com a percepção ilusória da tridimensionalidade e do movimento, além de estar sujeito a outros estímulos, como o tátil e o sonoro. 
O termo RA pode não apresentar uma relação conceitual contraditória entre as palavras que o constituem, como ocorre com o termo RV; todavia, a associaçáo entre as palavras realidade e aumentada pode levar à inclusáo de exemplos anteriores ao próprio desenvolvimento dessa tecnologia. Ao longo dos tempos acumularam-se os exemplos de interferências realizadas pela humanidade no mundo físico, das pinturas rupestres aos grafites dos centros urbanos. Nos dois casos é possível observar a inclusão de imagens e conteúdos simbólicos no mundo real, aproximando-os ou mesmo incluindo-os no território abrangido pelo conceito de RA. Contudo, as fronteiras que definem os conteúdos abarcados pela tecnologia da RA limitam o seu território aos conteúdos digitais, pois:

[...] a RA permite a sobreposição de informaçôes digitais no mundo físico. Ou seja, há um computador ou processador digital envolvido. As informaçôes digitais podem ser puramente sintéticas, como as de uma simulação em computador, ou podem ser cópias de informaçôes do mundo real representadas digitalmente. Não há restriçóes quanto ao sentido em que as informaçôes pertencem, ou seja, podem ser informaçôes visuais, auditivas ou relativas a olfato, paladar ou tato. A informaçáo pode ser estática, como uma fotografia digital ou modelo gráfico digital $3 \mathrm{D}$ ou uma gravação digital de som, ou pode ser baseado dinamicamente em uma simulação de computador com evolução no tempo, a partir de dados de sensores em tempo real ou outras fontes dinâmicas de informação (Craig, 2013, p. 16, tradução nossa).

$\mathrm{Na}$ RM (Figura 1), o ambiente real, a RV e a RA imbricam-se em um território cujos extremos delimitam uma contínua virtualidade (Milgram; Kishino, 1994).

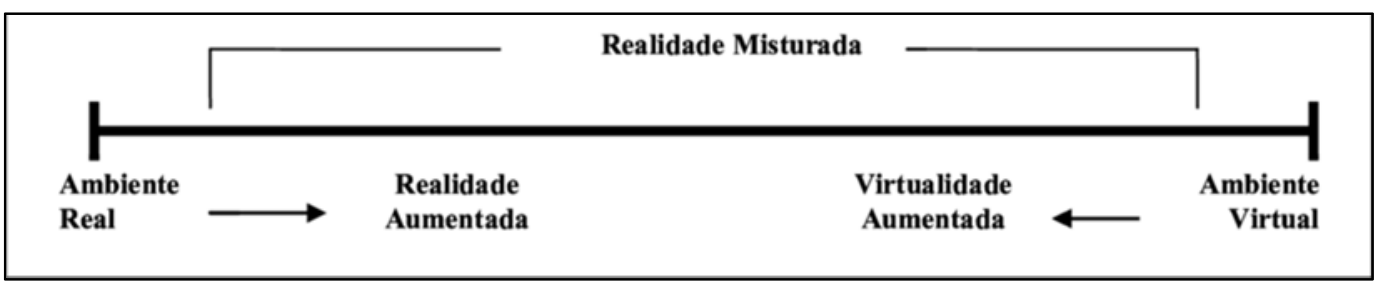

Figura 1 - Continuum de Virtualidade. Fonte: Milgram e Kishino (1994).

O crescente interesse dos setores produtivos e artísticos pela RA parte principalmente da mudança paradigmática impulsionada pelas novas tecnologias digitais, a possibilidade de interação com a imagem. Hoje, a imagem é manipulada, animada e adaptada aos ambientes virtuais através de recursos tecnológicos computacionais. A sua dimensão de simulacro é potencializada ao possibilitar ao observador que, além da simples manipulaçáo ou in- 
teração, o espaço da imagem seja habitado e explorado. A expressão entrar no quadro, até entáo empregada para designar uma experiência estética em que a obra envolvesse o observador e sua imaginação, hoje apresenta um sentido literal graças à RV. O observador pode entrar na imagem, habitá-la e vivenciá-la ${ }^{2}$. A interação ocorre tanto com o espaço presente na imagem e toda a sua profundidade ilusória, quanto com os elementos visuais que integram essa mesma imagem. Ao entrar na imagem, o observador inicia a experiência da imersão, efeito explorado pelas diferentes plataformas que utilizam a tecnologia da RV. Segundo Grau (2007, p. 30):

A maioria das realidades virtuais vivenciadas de forma quase total veda hermeticamente a percepção das impressóes visuais externas do observador, atrai sua atenção com objetos plásticos, expande perspectivas de espaço real no espaço de ilusão, observa a correspondência de cores e escala e, como o panorama, faz uso de efeitos de luz indireta para que a imagem apareça como a fonte do real. A intenção é instalar um mundo artificial que proporcione ao espaço imagético uma totalidade ou, pelo menos, que preencha todo o campo de visão do observador.

O Head-Mounted Display (HMD), popularmente conhecido como capacete ou óculos de RV, adaptado ao ecrã dos smartphones ou conectado a um computador, permite hoje ao observador transpor a linha divisória entre a realidade e o universo umbrático da imagem. Ao ser isolado em um simulacro e simultaneamente ao ser privado dos estímulos visuais do mundo tangível e circundante, o observador se torna apto para a imersão na imagem. A imersão em um novo campo visual fictício possibilita não apenas uma nova forma de fruição de imagens, como também experiências capazes de estimular outros sentidos, como a audição e o tato, potencializando sensaçóes e sentimentos como o medo ou a vertigem.

Diferentemente da experiência imersiva possibilitada pela ferramenta da RV, a RA emprega os displays visuais como lentes que permitem ao observador fundir dois mundos aparentemente distintos, o tangível e o digital. Essa fusão ocorre em um espaço de projeção, sendo a imagem real apenas um reflexo da paisagem observada pela lente dos aparelhos celulares ou webcams, ou seja, uma imagem ficcional. Na RA em dispositivos móveis, a imagem considerada real corresponde a uma projeção de pixels no ecrá, ordenados a partir dos dados capturados pela lente e processados por sensores eletrônicos. Portanto, a imagem considerada real, que em sua essência cor- 
responde a uma ficção, dialoga e se aproxima daquela classificada como virtual. Apesar da dimensáo ficcional apresentada pela realidade capturada e enquadrada pelas lentes dos smartphones, a sociedade contemporânea parece aceitar pacificamente e até demonstra certo entusiasmo em ter a percepção visual intermediada pelos ecrãs dos dispositivos móveis. Tal fenômeno poderia levar a uma aceitação da imagem obtida pelos smartphones em tempo real como a própria realidade, fazendo com que a percepção da natureza fora do enquadramento do display visual gere mais estranhamento do que a imagem enquadrada e projetada em sua superfície reflexiva e ficcional. Se aceitarmos as imagens projetadas a partir das lentes dos smartphones como fragmentos da realidade, as camadas de conteúdos digitais sobrepostas nesses fragmentos gerariam imagens marcadas pela hibridizaçáo entre o tangível e o digital, como afirmam Domingues e Venturelli (2007, p. 109):

O híbrido soma propriedades do ciber e torna-se cíbrido. O potencial do digital, levado ao paroxismo, incrusta virtual com virtual no espaço físico, homologando desejos ficcionais de viver em mundos paralelos. Objetos, cenas, visualização sintética, geografias misturadas são espaços e lugares cíbridos para a existência. A Realidade Aumentada e suas versóes tira o foco do virtual como evasáo do real e, dialeticamente, acentua a potencialidade do virtual ampliando a realidade.

$\mathrm{Na} \mathrm{RV}$ e na RA, assim como em qualquer ferramenta empregada para o processo de criaçáa, as possibilidades poéticas podem ultrapassar as funcionalidades originalmente previstas para tais recursos tecnológicos, como aconteceu com os cineclubes formados nas primeiras décadas do século XX por representantes das vanguardas europeias, como o dadaísmo e o surrealismo, pioneiros do cinema experimental.

Assim como os artistas dadaístas exploraram os recursos do cinema, como o stop motion ${ }^{3}$, transpondo elementos da linguagem pictórica para a cinematográfica e se apropriando dos recursos da linguagem do cinema para repensar a prática pictórica, muitos artistas hoje se apropriam dos recursos da RA com o intuito de repensar ou de expandir o processo de criaçáo. A possibilidade de fundir em um mesmo campo visual as imagens que circundam o observador com uma vasta gama de conteúdos digitais, articulando dados, imagens, arquivos audiovisuais permite que essa tecnologia dialogue com os mais diferentes interesses, do poético ao comercial, do lúdico ao crítico. Contudo, é importante observar que o emprego de uma determinada 
tecnologia nos processos artísticos implica certos riscos. Quanto mais a proposta artística subverter as funcionalidades da ferramenta, expandindo-as em função do aspecto poético, maior será a capacidade de o trabalho sobreviver à obsolescência da ferramenta; caso a proposta artística mantenha com a ferramenta uma relação de dependência, evidenciando apenas as funcionalidades desta, o trabalho possivelmente não sobreviverá quando a tecnologia utilizada se tornar obsoleta.

\section{Processos de Criaçáo entre a Arte e a RA}

Os processos de criação que entrelaçam os territórios da arte e da ciência ocorreram inúmeras vezes ao longo da história. $\mathrm{O}$ século $\mathrm{XX}$ apresentou uma profícua produção obtida a partir da articulação desses dois campos de conhecimento. Stelarc ${ }^{4}$ e Eduardo $\mathrm{Kac}^{5}$ são apenas alguns exemplos de artistas pioneiros que diluíram os limites entre a ciência e a arte ao articularem a engenharia, a genética e a anatomia, abordando tanto questóes conceituais quanto estéticas e criando métodos de trabalho voltados para as especificidades dos diálogos estabelecidos entre as tecnologias e o campo da arte. $\mathrm{O}$ desenvolvimento e a popularização das mídias digitais facultaram ao universo da arte a incorporação de determinadas tecnologias nos processos de criação, como a RV e a RA. Dessa forma, as últimas três décadas presenciaram o crescimento do número de trabalhos que permitem ao público uma imersão na imagem (RV) ou a inserção de conteúdos digitais em um espaço ou uma imagem tangível (RA).

Os experimentos artísticos que incorporam a RA ao processo de criação podem apresentar diferentes linhas exploratórias, sobrepondo camadas de conteúdos digitais nos mais distintos espaços e suportes. A performance body (2008), de Camila Hamdan, utilizou o corpo performático como suporte para o tangenciamento de conteúdos digitais através da RA. A performance propóe uma utilização criativa da computação ao objetivar a aplicação náo convencional da tecnologia da RA (Hamdan, 2015), possibilitando assim a visualização de conteúdos digitais para a obtenção de um corpo híbrido, constituído de carne e pixel:

A performance artística consistiu na ação de desenhar marcadores de RA, com uso de canetas e carimbos sobre a pele do público presente. Corpos foram submetidos a processos de demarcação semelhante à realização de uma 
tatuagem. Nesse trabalho, corpos foram editados por padróes simbólicos imagéticos próprios dos sistemas de RA e que, na ocasiáo, remeteram à transformação dos sujeitos em produtos artísticos móveis, sob o efeito dialético da construção da imagem corporal ampliada pela tecnologia, em um local de exposição e fruição artística (Hamdan, 2015, p. 277).

$\mathrm{O}$ ato de desenhar os marcadores ${ }^{6}$ de RA nos corpos do público demonstra como a artista integrou na performance um componente técnico do sistema de visualizaçáa em RA, situando-o no espaço poético de reconstrução simbólica do corpo. Para a consecução da performance body (2008), foi utilizada a ferramenta $A$ RtoolKit ${ }^{7}$, uma biblioteca de código aberto para o desenvolvimento de interfaces para RA. Essa ferramenta utiliza a visão computacional para o reconhecimento de marcadores, propiciando a sobreposição de conteúdos digitais sobre tais marcadores. O processo de criação de body (2008) náo ficou restrito ao uso criativo da tecnologia. A necessidade do emprego de marcadores para o tangenciamento dos conteúdos digitais no corpo possibilitou à performance, através da tatuagem, a utilização do símbolo copyleft ${ }^{8}$ para o desempenho de uma dupla função: atuar como marcador para o sistema de visualização da interface em RA e estruturar a dimensão conceitual da performance, pois, ao agir sobre o corpo carnal, o desenho do copyleft o transformou em um corpo tecnológico sujeito às normas de proteção da propriedade intelectual.

Ao propor a demarcação do copyleft sobre os corpos presentes na instalação, body (2008) introduziu o presente diálogo da modificação corporal pelo processo de ediçáo do corpo semelhante à tatuagem e atribuiu a ele um novo significado de existência simbólica de conteúdo informacional tecnológico, político e estético. A licença poética de uso dessa imagem no diferente modo de aplicação pela performance artística propóe uma reflexão sobre a liberdade de modificar o corpo humano e proteger outras versôes derivadas dessa modificação (Hamdan, 2015, p. 281).

A interface de RA desenvolvida para a performance body (2008) utilizou uma estrutura de hardware e software, incluindo uma webcam e um projetor para a visualização dos conteúdos digitais. Os recursos tecnológicos empregados foram instalados em um espaço expositivo e ocuparam duas áreas, uma destinada à interferência no corpo do público por meio do desenho do símbolo copyleft, onde estava disposta a webcam, e outra destinada à projeção da imagem do corpo com as asas digitais em RA (Figura 2). A in- 


\section{Revista Brasileira de Estudos da Presenca Brazilitan Journal on Presence Studies}

terface desenvolvida exigiu a instalaçáo dos equipamentos em um espaço fixo, uma vez que o sistema de reconhecimento visual do marcador e de visualização do conteúdo digital não estavam integrados em uma mesma estrutura de hardware, mas conectados através de periféricos. O desenho da estrutura tecnológica empregada no processo de criação da performance body (2008) fez com que o olhar do público percorresse, simultaneamente, os ambientes ocupados pelo corpo carnal e pelo corpo hibridizado por meio da sobreposiçáo do conteúdo digital em RA.

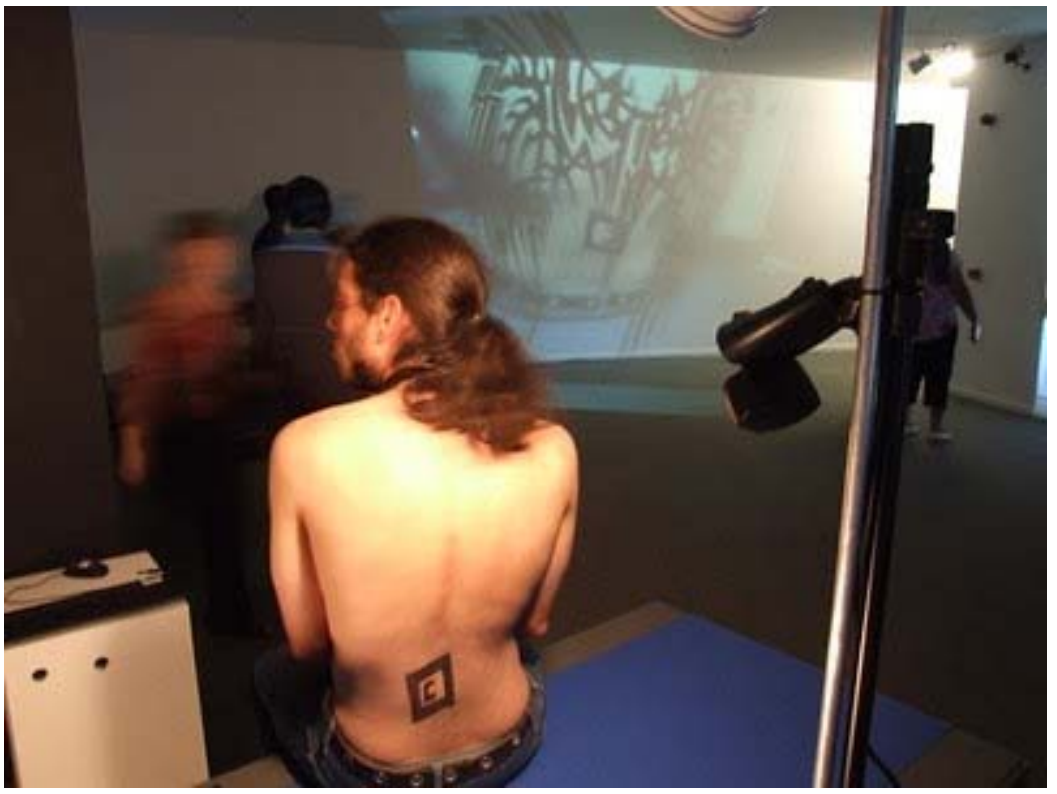

Figura 2 - body, Camila Hamdan (2008). Foto: licença Creative Commons. Fonte: <https://flic.kr/p/5vHYFb>.

A utilizaçáo da RA em experimentos artísticos não ficou limitada ao espaço expositivo e ao uso de estruturas tecnológicas complexas. A ampliaçáo dos recursos de hardware dos smartphones e tablets, acompanhada pelo desenvolvimento dos sistemas operacionais móveis, como o iOS e o $A n-$ droid' , possibilitaram que a tecnologia da RA fosse incorporada também aos dispositivos móveis. Esse processo foi potencializado com a disponibilização de kits de desenvolvimento de softwares, ou software development kit (SDK) com suporte para RA. Com a incorporação da RA aos dispositivos móveis, novas possibilidades surgiram para a apropriação dessa tecnologia nos processos de criaçáo artísticos, a exemplo do trabalho Parade to Hope (2011), de Mark Skwarek.

No dia 8 de abril de 2011, no cruzamento entre as ruas Lorimar e Maujer, no Brooklyn, Nova Iorque, uma série de eventos precedeu e anun- 
ciou um desfile grandioso e interminável em busca da esperança. Inicialmente, um estrondo ecoou no cruzamento entre as ruas, sendo sucedido pela formaçáo de um buraco do qual emanava um grande volume de fumaça. Em pouco tempo, esse buraco transformou-se em um vulcáo. Após a atividade vulcânica, um cânion se formou e, finalmente, das profundezas do cânion, saíram perfilados os integrantes do desfile. Os eventos descritos acima, cuja natureza fantástica gera incredulidade, integram o experimento de intervençáo urbana ativista em RA para dispositivos móveis Parade to Hope (2011), de Mark Skwarek. Nesse projeto, a tecnologia da RA para dispositivos móveis foi incorporada ao processo de criação, permitindo a intervenção virtual no espaço urbano com a inserção de camadas de conteúdos digitais. Todos os eventos descritos acima foram visualizados, no formato de conteúdos digitais animados, no ecrã de um smartphone através de um aplicativo de RA (Figura 3).

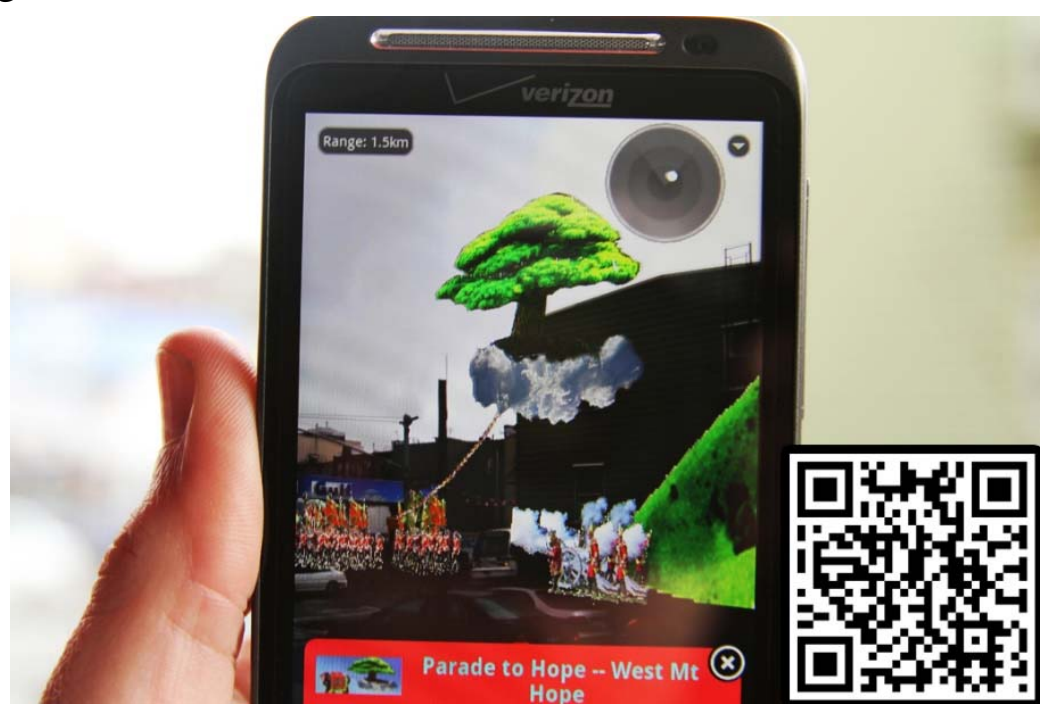

Figura 3 - Parade to Hope, Mark Skwarek (2011). Fonte: <http://paradetohope.wordpress.com/>.

Ao inserir camadas de conteúdos digitais no espaço urbano, Parade to Hope (2011) apropriou-se da RA móvel para o uso poético e ativista. A imaterialidade do processo de intervenção com a RA desresponsabiliza o artista em obter as eventuais e necessárias autorizaçóes para a montagem e exposição do seu trabalho no espaço público, oportunizando a intervenção ativista:

A RA permite que ideias e mensagens sejam sobrepostas no mundo real digitalmente com o objetivo de alcançar objetivos ativistas. Os ativistas podem criar trabalhos com software como Layar e Junaio para fazer seus próprios 
Revista Brasileira de

Estudos da Presenca

Brazilian Journal on Presence Studies

protestos baratos usando seus smartphones pessoais. Ter acesso a ferramentas de baixo custo permite mais liberdade para criar e distribuir mensagens ativistas enraizadas no mundo físico. O objetivo é geralmente para que a mensagem alcance e mobilize o maior público possível. A RA pode transformar a comunidade global em um público e, ao mesmo tempo, dar voz a eles (Skwarek, 2014, p. 7, tradução nossa).

Body (2008) e Parade to Hope (2011) possuem em comum a incorporaçáo da RA em seus processos de criação. Contudo, as ferramentas tecnológicas e os sistemas de visualizaçáo utilizados em cada trabalho distinguemse. Essas diferenças podem ser justificadas tanto pela dimensão conceitual de cada proposta, quanto pelos recursos tecnológicos disponíveis no período de desenvolvimento de cada trabalho. As relações com a tatuagem e com a ação performática reforçaram o emprego do sistema de reconhecimento de marcadores em body (2008), já Parade to Hope (2011) utilizou dados geográficos para o georreferenciamento do conteúdo digital. As imagens digitais presentes nas duas obras recorreram ao efeito de animaçáo, especialmente por estarem associadas a açóes, como a dinâmica do movimento das asas ou da marcha de um desfile. Portanto, além do uso criativo da linguagem de programaçáo para o desenvolvimento das interfaces em RA, os dois projetos exigiram conhecimentos em edição de imagem e vídeo digital, além de modelagem e animação tridimensional. Nos dois casos, a relação interdisciplinar entre as diferentes ferramentas tecnológicas empregadas foi orientada pelas diretrizes conceituais e estéticas comuns a cada processo de criação.

A análise de dois trabalhos artísticos que recorreram à RA, com ênfase para a poetizaçáo dessa ferramenta tecnológica, contribui para mapear as estratégias adotadas para o planejamento de novas possibilidades conceituais e estéticas para o uso artístico da RA. Esses trabalhos fornecem material para auxiliar no desafio de responder ao questionamento apresentado na parte introdutória deste artigo, pois a questáo abordada permite correlacionar ambos em um único processo de criação, que utilize a RA em dispositivos móveis para a inserção de conteúdos digitais autorreferenciais no espaço urbano, construindo territórios híbridos para a ação performática. A reuniáo de um conjunto heterogêneo de componentes no processo de criaçáo, como a ferramenta da RA, a intervenção urbana, conteúdos digitais autorreferenciais e a ação performática exigem a participação de um agente aglutinador. Parade to Hope (2011) recorreu a uma narrativa para a gênese do desfile, 
constituída por uma sucessão de eventos. A utilização de estratégia semelhante permite reunir os componentes acima listados em torno de um personagem e de sua história. Assim, no contexto da ação performática Inter Faces, surge a figura do peregrino e sua deambulação, a partir da relaçáo entre a ação performática e a RA para a construçáo de diálogos entre espaços simultaneamente presentes/ausentes e o corpo do performer. Para tanto, o tangível (o corpo performático) e o digital (autorreferências) são articulados em um espaço fluido e em contínua transformaçáo, o espaço real e a sua expansão por meio de conteúdos digitais, alinhavando interfaces tangíveis e virtuais em um território híbrido.

\section{Inter Faces entre o Corpo Performático e a RA}

O processo de criação das performances de Inter Faces percorreu cinco fases distintas: a análise comparativa de trabalhos artísticos em RA, o estudo técnico das ferramentas de software para o desenvolvimento de aplicativos de RA com suporte para sistemas operacionais móveis, a criação da estrutura conceitual das açôes performáticas, a modelagem digital dos conteúdos autorreferenciais e a apresentação das performances. Dentre os trabalhos artísticos caracterizados pela utilização da tecnologia de RA, body (2008) e Parade to Hope (2011) foram selecionados para a análise comparativa por apresentarem, em seus processos de criaçáo, aproximaçóes com o questionamento presente na gênese da investigação.

O desenvolvimento do aplicativo de RA para sistemas operacionais móveis exigiu o conhecimento técnico do software Unity ${ }^{10}$, adquirido através do processo de autoaprendizagem possibilitado por vídeos tutoriais disponíveis na internet. O software permite a utilização de SDK para RA. Para os primeiros experimentos, optou-se pelo SDK Vuforia ${ }^{11}$, que utiliza o sistema de visualização computacional para o rastreamento de marcadores e não exige o conhecimento prévio da linguagem de programação, possibilitando assim a um maior número de pessoas o acesso aos recursos da RA. A câmera de RA presente no SDK Vuforia permite o reconhecimento de diferentes tipos de marcadores, bidimensionais e tridimensionais, monocromáticos e policromáticos. O SDK Vuforia possui suporte para várias plataformas e sistemas operacionais, contudo, optou-se pelo sistema operacional Android para o teste do primeiro aplicativo desenvolvido. 


\section{$x^{\text {romanat }}$ Brasileira

Entre os dois trabalhos analisados e a fase inicial do processo de criação da ação performática em RA, Inter Faces, há um intervalo de tempo de aproximadamente uma década, que possibilitou avanços no campo da RA, permitindo tanto a sua popularizaçáo, como o acesso facilitado às ferramentas de desenvolvimento, seja pelos programadores ou pelo público leigo. Esses fatores viabilizaram que os experimentos iniciais do projeto de investigação Inter Faces ocorressem sem a necessidade do conhecimento da linguagem de programaçáo.

Os conteúdos digitais desenvolvidos para as primeiras exploraçôes com RA e, consequentemente, para a primeira versão do aplicativo, foram criados a partir de autorretratos do artista (primeiro autor deste artigo) com imagens autorreferenciais por intermédio da apropriação da face do performer e de objetos retirados do seu imaginário (Figura 4).
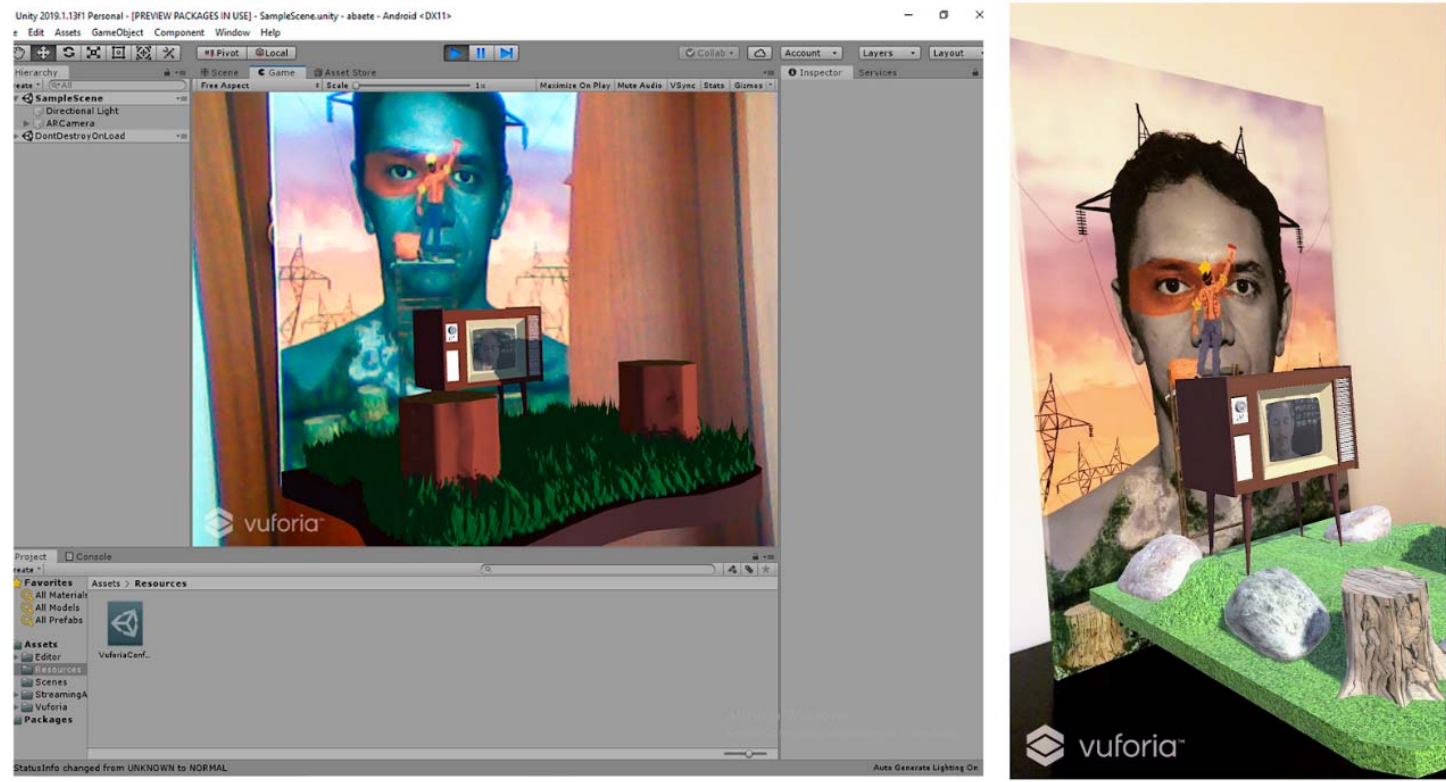

Figura 4 - Imagem do autorretrato do artista e da visualização das primeiras experiências em RA utilizando a câmera do computador e, posteriormente, um smartphone. Fonte: Arquivos do autor (2018).

Foi esse mesmo universo autorreferencial que influenciou a criação dos marcadores para a sobreposição dos conteúdos digitais sobre o corpo performático.

A primeira apresentaçáo pública e experimento prático com performance foi realizado no contexto da exposição colectiva Timelessness ${ }^{12}$ (Figura 5), como parte integrante da Campus Exhibition do 40 Ars Electronica Festival, em Linz - Áustria. Nesse evento, ao longo de cinco dias, a instala- 


\section{Revista

ção Inter Faces foi apresentada através das performances (três sessôes diárias), dois autorretratos em pintura digital e um tablet para exploraçáo dos respectivos conteúdos em RA.

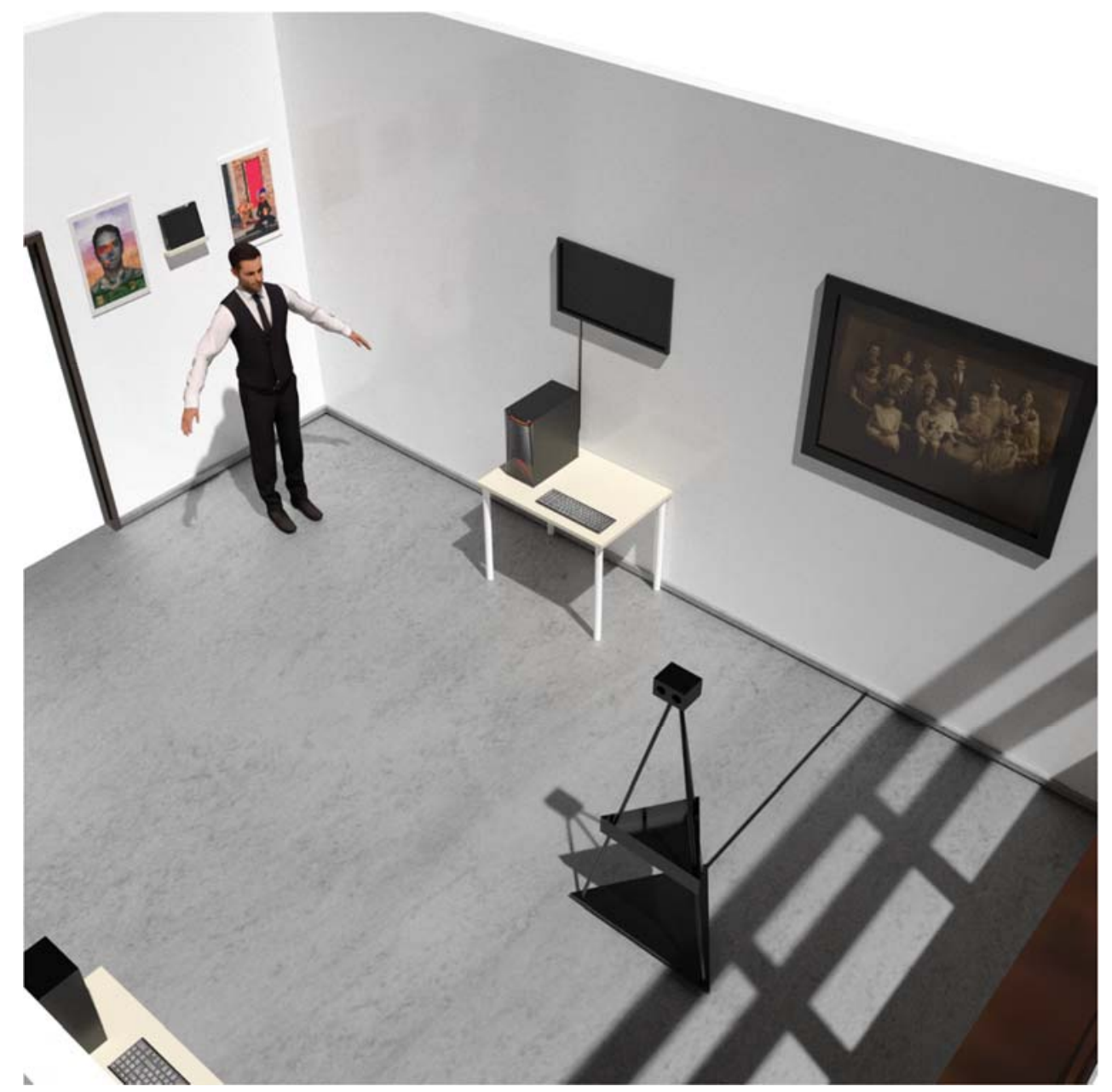

Figura 5 - Modelo tridimensional desenhado para planejamento da exposição coletiva Timelessness, Campus exhibition. 40 Ars Electronica Festival, Linz - Áustria (2019). Fonte: Arquivos do autor (2019).

Em tal evento, para as performances, marcadores impressos foram apresentados sucessivamente em diversas partes do corpo do performer, permitindo a sobreposição de conteúdos digitais através do aplicativo de RA desenvolvido especificamente para esse evento e instalado no tablet disponibilizado na exposição. Foram criados seis marcadores, cada um apresentando um conteúdo digital específico, como ilustra a Figura 6. Essa primeira experiência foi concebida a partir da proposta inicial do projeto, que tinha por objetivo a utilização de conteúdos digitais autobiográficos manipulados pelo performer mediante marcadores dispostos em seu corpo. 

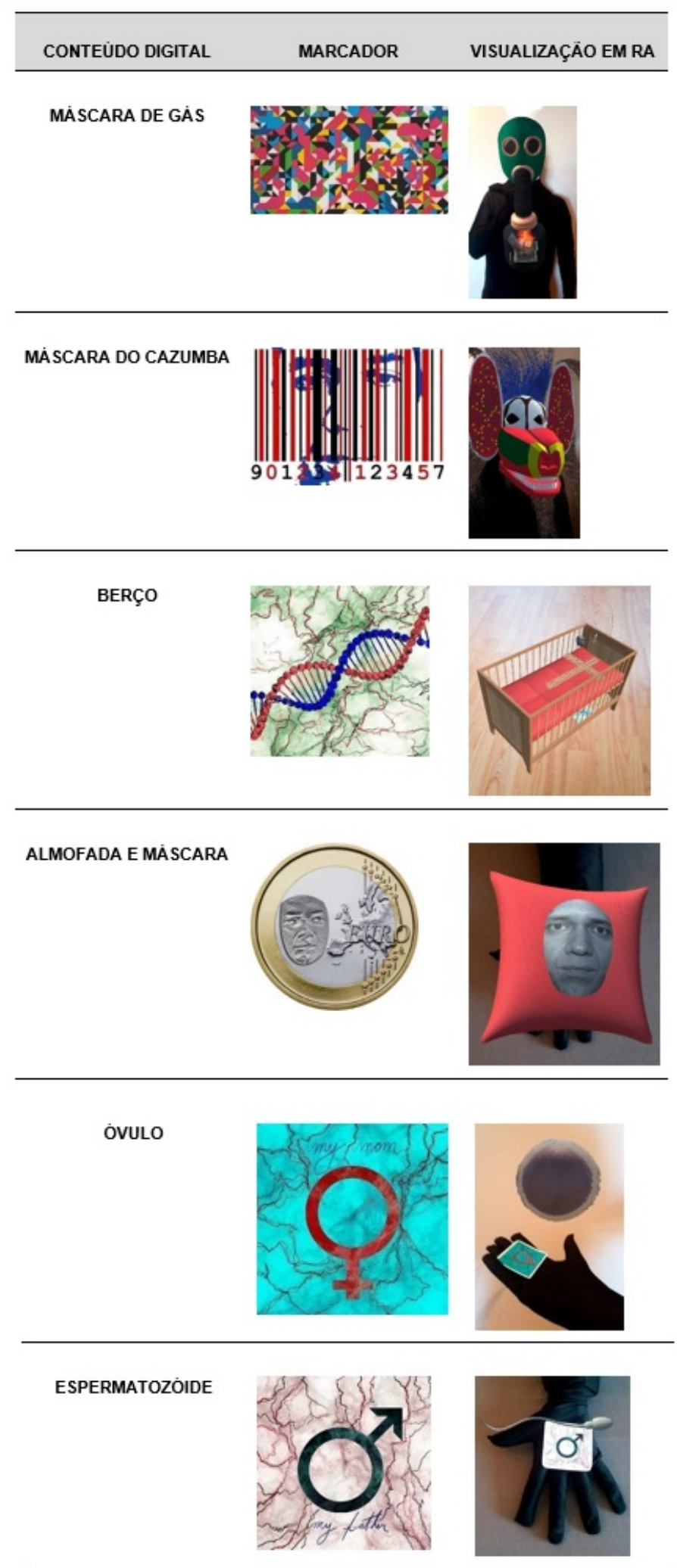

Figura 6 - Alvos e conteúdos em RA da instalação e performance Inter Faces apresentadas no âmbito da exposição Timelessness, 40 Ars Electronica Festival, Linz, Áustria (2019). Fonte: Arquivos do autor (2019). 


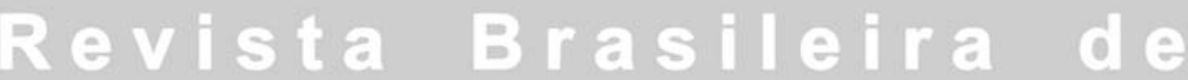

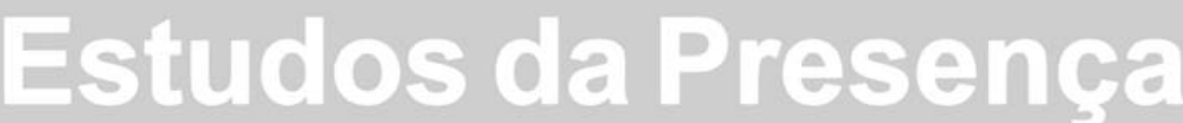 Brazilitan Journal on Presence Studies}

Para a demonstração dos conteúdos digitais sobre o corpo, uma segunda pele preta foi utilizada com a finalidade de anular a identidade do performer, destacando os marcadores manipulados durante a demonstraçáo, bem como a visualização dos objetos digitais. Foram utilizadas duas máscaras digitais visualizadas através da RA (Figura 7). Estando a investigação apoiada sobre três eixos - a performance, o autorretrato e a RA -, a dimensão autorreferencial presente nos conteúdos digitais criados para esse primeiro contato com o público foi trabalhada de duas formas: por meio da exposiçáo fixa de dois autorretratos com conteúdos digitais em RA e da performance, que utilizou a imagem do performer em dois marcadores e em três conteúdos digitais. Objetos digitais em RA alusivos à história do performer também foram empregados, da concepção biológica do corpo com o espermatozoide e o óvulo, ao processo de formação da identidade cultural, simbolizado pela máscara do cazumba ${ }^{13}$.

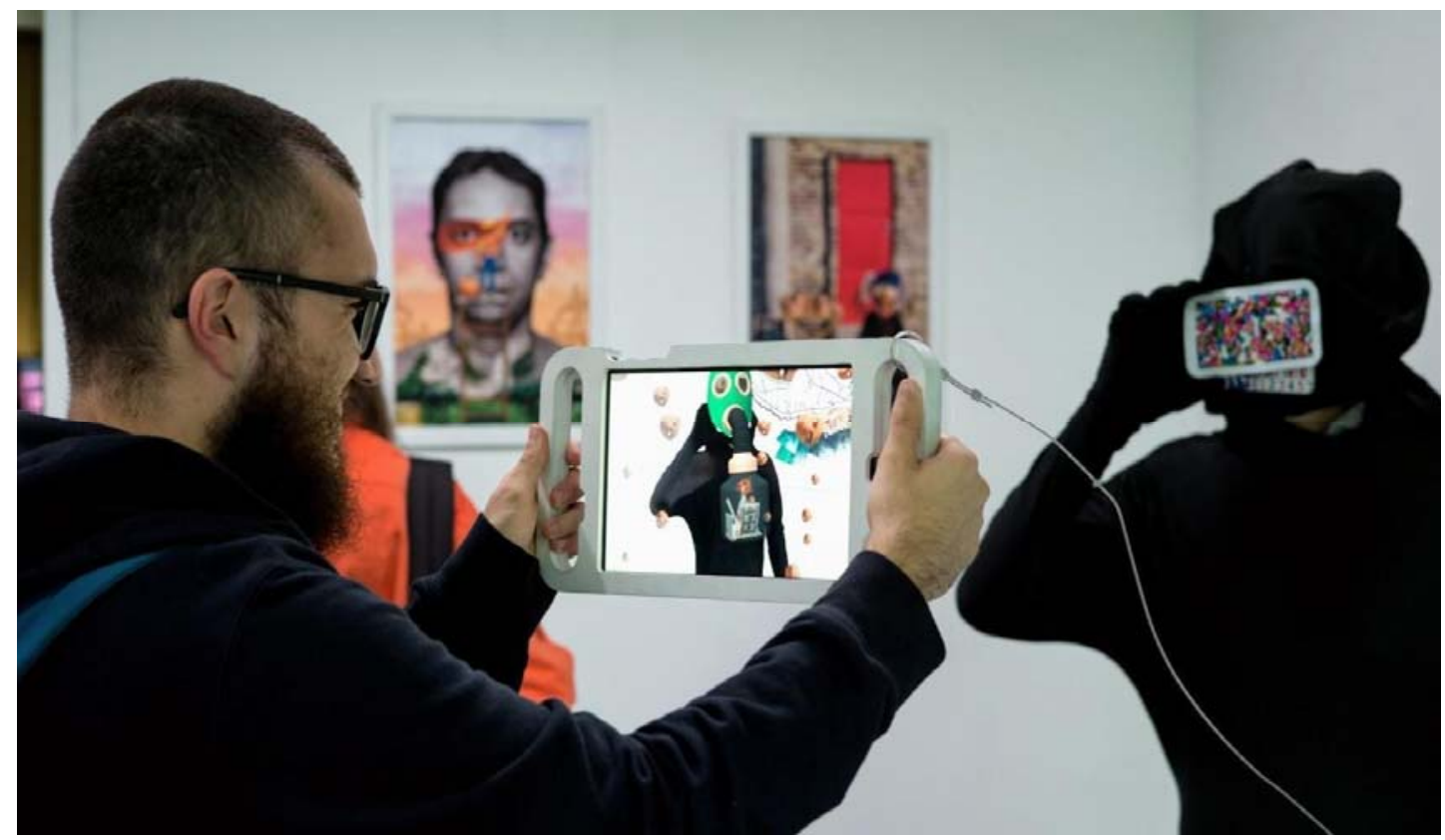

Figura 7 - Demonstração do emprego de conteúdos digitais sobre o corpo performático com RA. Foto: Rita Carvalho | MILL. 40 Ars Electronica Festival, Linz - Áustria (2019). Fonte: Rita Carvalho | MILL (2019).

Após cada performance, a participação e a reação do público foram registradas e posteriormente analisadas, levando às seguintes constataçôes, informadas pelos métodos de avaliação em Interação Humano-Máquina (Hannington; Martin, 2012): 
- os conteúdos digitais com algum tipo de animação atraíam mais a atençáo do público, a exemplo da máscara de gás, que apresentava a animação em dois elementos, o fogo e a fumaça;

- o tamanho dos marcadores exigia que o público se aproximasse para que os conteúdos digitais fossem reconhecidos, o que de certa forma impedia ou dificultava a visualização do corpo do performer em sua totalidade. Apesar de o aplicativo permitir a visualizaçáo de conteúdos a partir de marcadores simultâneos, o público direcionava o tablet para pontos específicos olhando os conteúdos individualmente, e não em conjunto;

- a qualidade da câmera do tablet, a iluminação do ambiente e o tamanho dos marcadores interferiam no seu reconhecimento pelo aplicativo de RA;

- o uso de marcadores impressos limitava a movimentaçáo do público com o tablet a um ângulo inferior a $120^{\circ} \mathrm{em}$ torno do performer;

- de forma geral, o público demonstrou surpresa ao observar o conteúdo digital sobre o corpo; todavia, como consistia numa performance integrada numa exposição no âmbito de um festival tão vasto ao longo de apenas alguns dias, já era esperado que esse interesse rapidamente se dispersasse após experienciar apenas uma parte, como demonstração, não permanecendo durante a totalidade da performance. Por essa razáo, a performance foi adaptada para que a duraçáo planejada inicialmente para dez minutos viesse a ser reapresentada como uma demonstraçáo sintetizada para cerca de cinco minutos.

A partir de tais consideraçóes, percebeu-se que a utilização de marcadores para sobrepor conteúdos digitais ao corpo do performer demonstrou pouca robustez, levando à exploração de outra interface de RA sem que o objetivo principal da investigaçáo fosse comprometido. Diferentemente da abordagem adotada pela ação performática body (2008), que empregou um sistema de visualização fixo, uma ampla área de projeção e um único marcador desenhado sobre o corpo do público, Inter Faces empregou seis marcadores e reduziu o campo de visualização para os limites do ecrã de um tablet de 10.1. A utilizaçáo dos dispositivos móveis pelo público para a fruição da ação performática é um ponto fulcral da investigação. O projeto prevê em sua fase final a disponibilização do aplicativo para a instalação nos smartphones do público, permitindo a mobilidade e a individualidade du- 
rante a fruição da performance. Destarte, a necessidade de manter um posicionamento da câmera de RA próximo dos marcadores, para o seu eficaz reconhecimento, pode configurar um desafio caso sejam utilizados simultaneamente vários dispositivos para a visualização dos conteúdos digitais.

$\mathrm{Na}$ exploração seguinte, em substituição aos marcadores, foi feita a opção pelo georreferenciamento de conteúdos digitais em espaços tangíveis, permitindo assim que a açáo performática ocorresse em um território híbrido. Dessa forma, a relaçáo entre o corpo e os conteúdos em RA seria preservada e a visualizaçáo dos conteúdos digitais não ficaria condicionada ao reconhecimento de marcadores pela câmera do dispositivo móvel, mas sim pelo reconhecimento das coordenadas presentes na configuração do aplicativo pelo GPS do dispositivo. Outro aspecto importante corresponde ao posicionamento do público em relaçáo ao performer. Náo havendo a necessidade do reconhecimento de marcadores pelo aplicativo em RA, o público náo necessitaria de um posicionamento próximo ao performer para visualizar o conteúdo digital ou a ação performática. Tal mudança implicou alteraçóes na estrutura conceitual da performance e, consequentemente, nos conteúdos digitais. Os pequenos objetos digitais carregados de memória foram entáo transfigurados em territórios híbridos e o corpo, destituído de identidade, metamorfoseou-se na figura de um peregrino, personagem concebida para habitar o espaço performático em RA.

O deslocamento da performance Inter Faces do espaço expositivo para o espaço urbano, em vista da substituiçáo do sistema de reconhecimento de marcadores pelo sistema de georreferenciamento de conteúdos digitais, denota uma aproximação com o trabalho Parade to Hope (2011). A RA em dispositivos móveis viabiliza a inserção de camadas de conteúdos digitais no espaço público, expandindo o processo de intervenção urbana. A ressignificação do ambiente mediante a inclusão de novas estruturas arquitetônicas, com imagens, vídeos e animaçôes, permite ao processo de intervençáo no espaço público incursões de caráter ativista ao abordar questóes sociais, ambientais e políticas.

A reestruturação da performance em função dos novos aspectos técnicos, com a substituição do sistema de marcadores pelo sistema de georreferenciamento para a utilização dos conteúdos digitais, propiciou a ampliação da dimensáo conceitual do projeto. A manipulação de objetos digitais com 
conteúdos autorreferenciais limitava a ação performática ao corpo, desprezando as potenciais relaçóes simbólicas oriundas da ocupação de diferentes contextos espaciais pela ação performática em RA. O olhar centrado no corpo, colocando-o como um recordatório para as memórias do performer trazia reduzidas possibilidades de diálogo com questóes políticas, sociais e ambientais que atuam diretamente na construção da identidade do performer, bem como na forma como este se insere e se percebe no mundo. A ocupaçáo do espaço público trouxe ao projeto a oportunidade de associar a ação performática, o aspecto autorreferencial e a RA à abordagem ativista, reunindo-os em atos públicos cuja dimensão de protesto é gradualmente alinhavada com a relaçáo entre o corpo performático e o espaço urbano. A investigaçáo deixa de estar associada a uma demonstraçáo do emprego da RA em açóes performáticas para atuar como um exemplo de artivismo.

Artivismo é um neologismo conceptual ainda de instável consensualidade quer no campo das ciências sociais, quer no campo das artes. Apela a ligaçóes, táo clássicas como prolixas e polémicas entre arte e política, e estimula os destinos potenciais da arte enquanto ato de resistência e subversão. Pode ser encontrado em intervençôes sociais e políticas, produzidas por pessoas ou coletivos, através de estratégias poéticas e performativas (Raposo, 2015, p. 5).

$\mathrm{O}$ personagem do peregrino e a sua peregrinação encontram em suas origens o vislumbre de uma possibilidade: a ação performática no continuum da realidade. Tal circunstancialidade enseja desafios técnicos e conceituais, que podem ser superados a partir da análise comparativa de trabalhos artísticos que tenham enfrentado dificuldades semelhantes, notadamente pelo emprego dos mesmos recursos tecnológicos. A análise das obras body (2008) e Parade to Hope (2011) permitiu à investigaçáo Inter Faces identificar e comparar os processos de criaçáo dos dois trabalhos, evidenciando em ambos a importância do discurso conceitual para a subversão da tecnologia utilizada. $\mathrm{O}$ emprego da RA náo ficou restrito às funcionalidades da ferramenta. Uma relação mútua de ressignificação foi estabelecida, pois, enquanto o conceito poetizava a ferramenta, a ferramenta materializava o conceito.

\section{O Caminhar por uma Paisagem Híbrida}

A nova versão da performance Inter Faces, com a substituição do formato de câmera de RA utilizada para os conteúdos digitais autorreferenciais, 
contribui para sedimentar a sua estrutura conceitual na relação entre a RA, o autorretrato e a performance. Alicerçando tal estrutura está o peregrino, que dilui as fronteiras ao lançar-se em uma jornada que o levará a espaços cujos limites e estruturas foram redefinidos por meio da tecnologia da RA. Essa reformulação permite expandir o espaço urbano ao interferir nos fluxos cotidianos, se apropriando da dinâmica própria das cidades, pois "o espaço público se configura por sua multiplicidade de fluxos, não como território estanque" (Ferreira, 2019, p. 5). Todo o peregrinar é motivado pelo desejo de alcançar um local sagrado, um santuário que existe em latência, mas cuja potência será manifestada apenas com a chegada da peregrinação a esse fim.

A jornada do peregrino foi concebida para ocorrer a partir da intervenção em quatro locais distintos, através da sobreposição de conteúdos digitais em RA no espaço público. $\mathrm{O}$ processo de intervenção possibilita à performance o redimensionamento simbólico da paisagem, com a inclusáo de estruturas arquitetônicas ou personagens virtuais. $\mathrm{O}$ registro de todas as etapas do processo de peregrinação é realizado no Facebook e um blog, cujas contas foram criadas exclusivamente para a documentação e divulgação da performance na internet ${ }^{14}$. O aplicativo a ser desenvolvido para os dois últimos momentos da ação performática será disponibilizado em lojas virtuais para os sistemas android e $i O S$. Dessa forma, o público terá a viabilidade de utilizar o próprio smartphone para visualizar o conteúdo digital.

Dos conteúdos digitais criados para a performance, um personagem virtual foi concebido para orientar e acompanhar a figura do peregrino durante toda a jornada - o Anjo da Anunciação (Figura 8). Esse conteúdo digital apresenta ao público a figura do peregrino contextualizando-o com os espaços ocupados pela ação performática. $\mathrm{Na}$ face do anjo reflete-se a do performer, aspecto que reforça a utilização dos conteúdos digitais autorreferenciais. A inserção da figura do anjo, como conteúdo digital, em um espaço tangível (a Praça do Comércio, em Lisboa), permitiu ao performer a primeira experiência de articulaçáo do corpo com um conteúdo digital. 


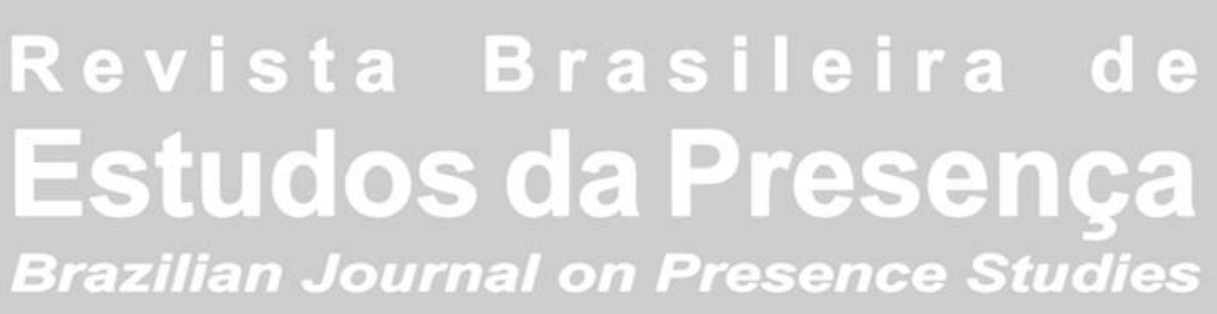

E-ISSN 2237-2660

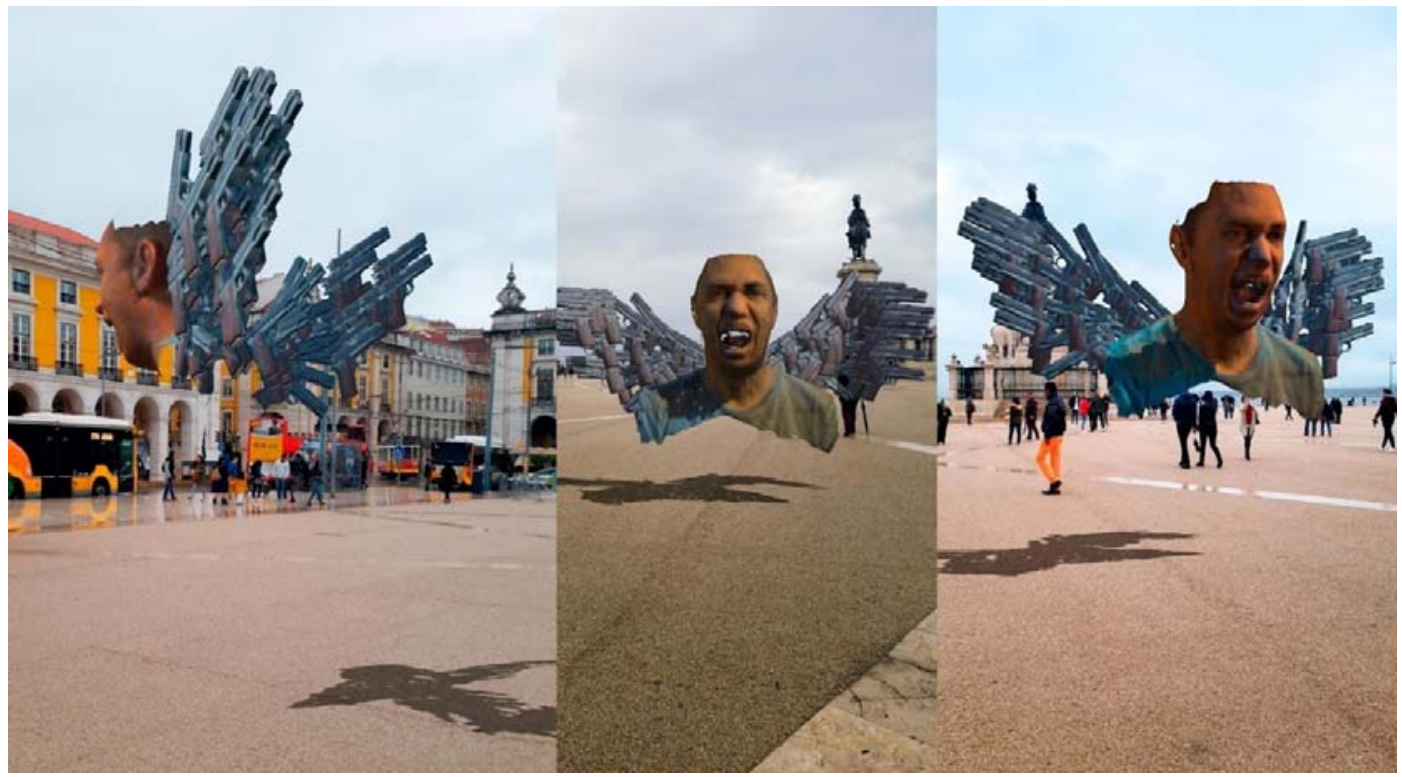

Figura 8 - Anjo da Anunciação na Praça do Comércio em Lisboa / Portugal. Fonte: Arquivos do autor (2019).

O primeiro momento da saga do peregrino ocorreu sem que o aplicativo em RA para dispositivos móveis estivesse liberado para download. Por tratar-se de uma primeira experiência, optou-se por observar a reação dos transeuntes frente ao comportamento invulgar de um indivíduo que emprega o smartphone para ver algo que não está presente no espaço. Essa primeira experiência também permitiu analisar o comportamento do aplicativo em $\mathrm{RA}$, especialmente quanto ao georreferenciamento do conteúdo digital à animação, à projeção da sombra e à relação desse mesmo conteúdo com o espaço circundante, além de eventuais falhas não previstas que o aplicativo pudesse apresentar. Portanto, essa iteração da performance também correspondeu a um teste de usabilidade do software (Hannington; Martin, 2012), funcionando quer como elemento crítico da garantia de qualidade do software, quer como revisão final do projeto (Pressman, 2011).

$\mathrm{Na}$ abertura da $11^{\mathrm{a}}$ edição do INSHADOW: Lisbon Screendance Festival ${ }^{15}$ ocorreu o segundo momento da peregrinação com a inclusão da performance Inter Faces na programação do evento. Para esse segundo momento, além do Anjo da Anunciação, um novo conteúdo digital foi desenvolvido. A imagem do performer foi utilizada para uma interpretação visual do orixá Exu ${ }^{16}$. Por tratar-se de uma divindade que está associada aos caminhos e que exerce o papel de mensageiro entre a humanidade e o mundo espiritual, a figura de Exu foi apropriada para a criação de uma nova divindade, um ser que zela pelos caminhos entre o tangível e o digital, que orienta os aventureiros que se lançam 
pelos caminhos que conectam e transformam a matéria em pixel ou que sobrepóem o pixel à matéria. Tal relaçáo pode ser facilmente estabelecida, pois:

Exu é o princípio, o meio e o fim. Exu está na árvore, no rio, no peixe, no pássaro, na pedra e em todo ser vivente. Como elemento energético dinamizador e plasmador, ele é o que desenvolve, mobiliza, faz crescer, transformar. É o que faz comunicar no incessante fluxo das vivências cotidianas entre o Orun e o Aiyê, o mundo espiritual e o mundo natural. Ele é o tudo e o nada. Seu jeito buliçoso de existir encontra ressonância no pensamento filosófico de um universo sem lógica. Um universo de lógicas infinitas, um universo polilógico (Machado, 2010, p. 11).

Para essa divindade foi elaborado um altar ornado pela imagem do orixá e ladeado por dois objetos, uma ânfora com fogo e o seu símbolo, o tridente (Figura 9). Esse conteúdo digital proporciona a apropriação e expansão do sincretismo religioso ao integrar à representação visual de Exu a imagem do performer, delegando-lhe novas atribuiçóes. A sincretizaçáo, nesse caso, mescla aos símbolos religiosos o autorretrato e a RA, estabelecendo trânsitos entre o real e o virtual. O altar imaterial invade o espaço tangível edificando as estruturas digitais necessárias para o desenvolvimento da performance, com o transitar do corpo performático por territórios híbridos.

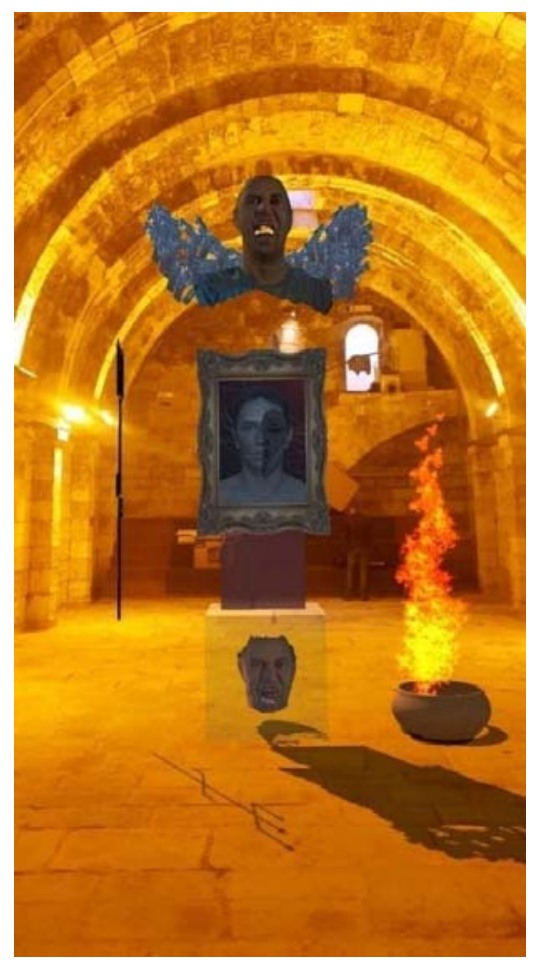

Figura 9 - Altar à Exú Digital. 11º INSHADOW 2019.

Fonte: Arquivos do autor (2019). 


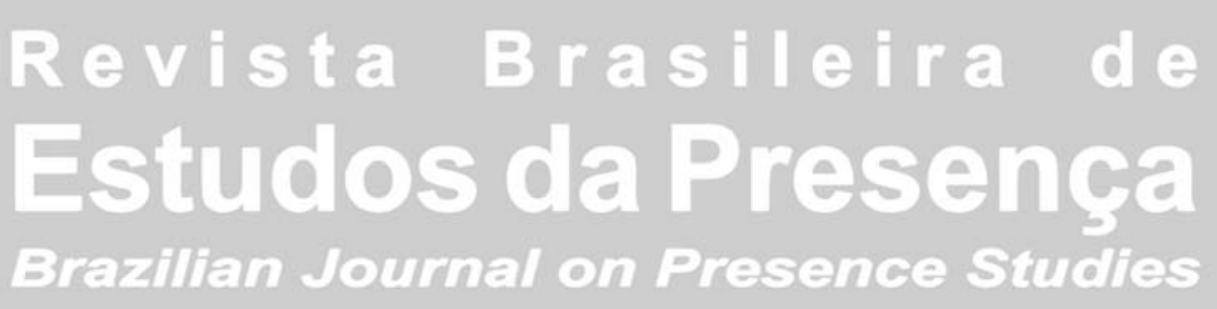

E-ISSN 2237-2660

Para assegurar ao público a visualização do conteúdo digital, o performer utilizou um ampliador de ecrá possibilitando o aumento da área de visualização do smartphone empregado de 5,5" para 8,6". Apesar de o aumento da área de visualização não ter sido substancial, um maior número de pessoas conseguiu se reunir em torno do ecrá suspenso para acessar o conteúdo digital (Figura 10).

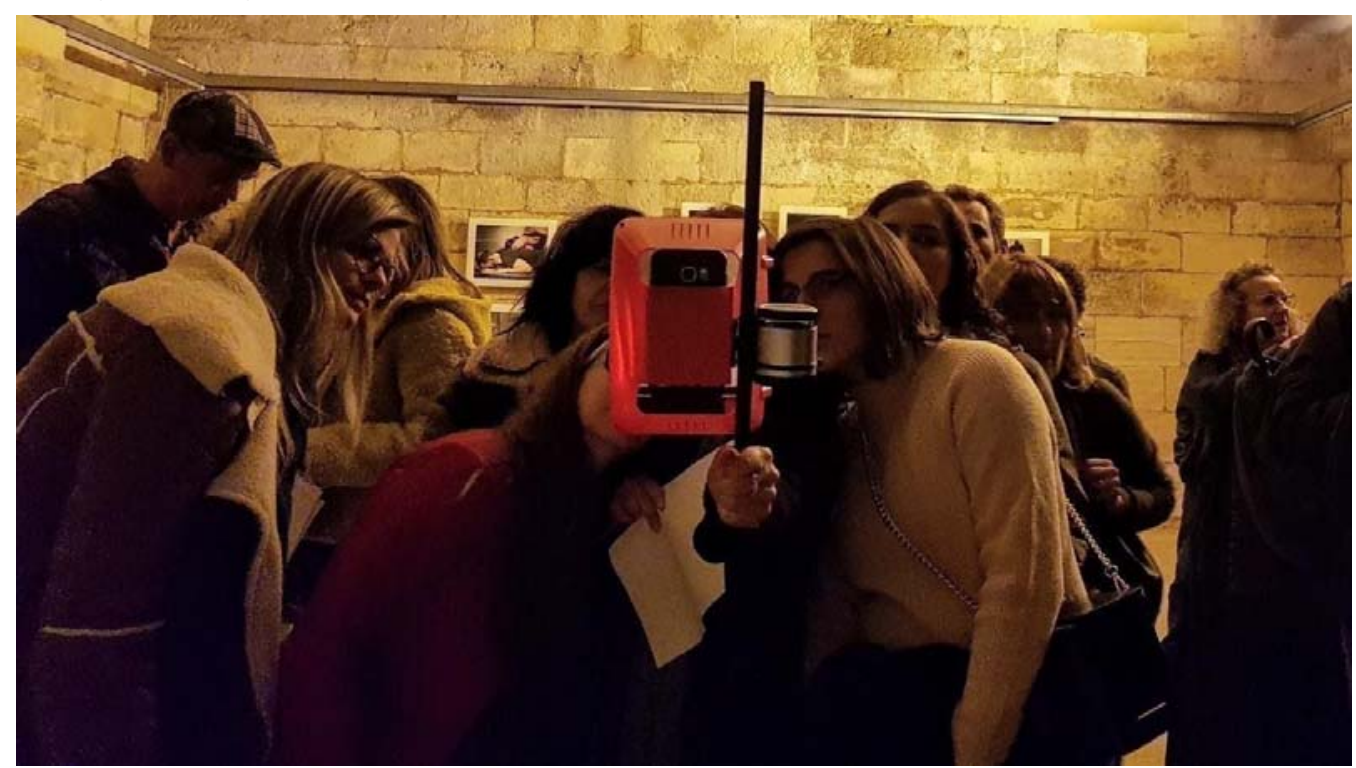

Figura 10 - Público observando o conteúdo digital através do ampliador de ecrã. 11 INSHADOW 2019. Fonte: Arquivos do autor (2019).

O santuário foi concebido para encerrar a jornada do peregrino e apresentar a dimensão ativista da performance. Nesse espaço onde o tangível e o digital se conectam, o efeito temporário de sacralização do território profano ganhou uma dimensáo política. O santuário homenageia seis pessoas, vítimas da violência por lutarem em defesa do meio ambiente e dos direitos humanos - Marielle Franco, Chico Mendes, José Oliveira Guajajara, Nilce de Sousa Magalhães, Dorothy Stang e Rosenildo Pereira de Almeida (Figura 11). Seis mártires da violência no Brasil. $O$ santuário tem por objetivo não apenas atuar como um território de homenagens, mas também como um território de memória e um mecanismo de clamor por justiça. Dessa forma, é esperado que a utilização das redes sociais como plataformas de documentação e publicização da performance atraia um determinado número de pessoas para participar do final da peregrinação ${ }^{17}$, de modo a garantir a dimensão de ato público e reforçar o caráter de protesto presente em seu conceito. Tal fato justifica a escolha dos pontos em que o santuário foi georreferenci- 


\section{$x^{\text {romanat }}$ Brasileira

ado. $\mathrm{Na}$ versão seguinte da performance, as 27 capitais brasileiras serão ocupadas pelo santuário, estando este sempre situado em frente a um tribunal de justiça. $O$ peregrino encerrará a sua peregrinação no santuário georreferenciado em Brasília, em frente ao Ministério da Justiça, mas qualquer pessoa poderá visitá-lo em cada uma das capitais brasileiras, desde que possua o aplicativo instalado em seu smartphone.

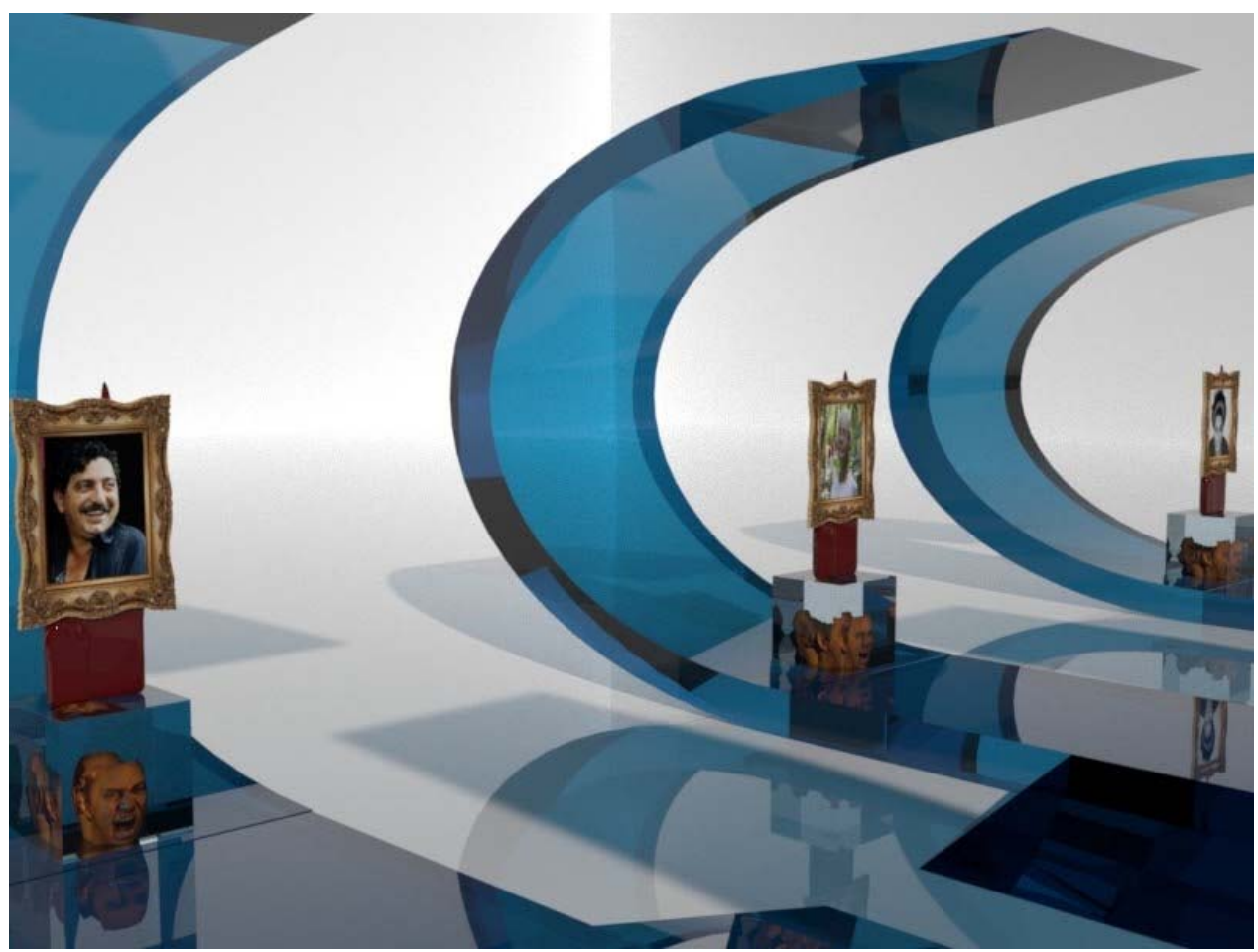

Figura 11 - Modelo tridimensional do santuário com as imagens dos mártires. Fonte: Arquivos do autor (2020).

Criar uma estrutura arquitetônica na escala de um santuário, construíla em 27 cidades diferentes e deixá-la permanentemente exposta em espaços públicos corresponderia a uma tarefa gigantesca sem o uso da tecnologia da RA. Ocupar espaços públicos com uma estrutura arquitetônica digital, criando um terreno híbrido passível de ser habitado pelo corpo performático, é uma das possibilidades do uso poético da RA (Figura 12). O peregrino e o seu caminhar, o Anjo da Anunciaçáo e o Santuário dos Mártires do Nosso Tempo integram um conjunto de lentes que empregam a RA para além do campo do entretenimento ou dos setores produtivos. A apropriaçáo do espaço público com conteúdos digitais através da RA, além da proposta apresentada pela performance Inter Faces, pode ser empregada de forma ampla pelas poéticas contemporâneas, ou pelos movimentos ativistas. Nos dois casos, as mensagens germinadas digitalmente no espaço público podem ser 


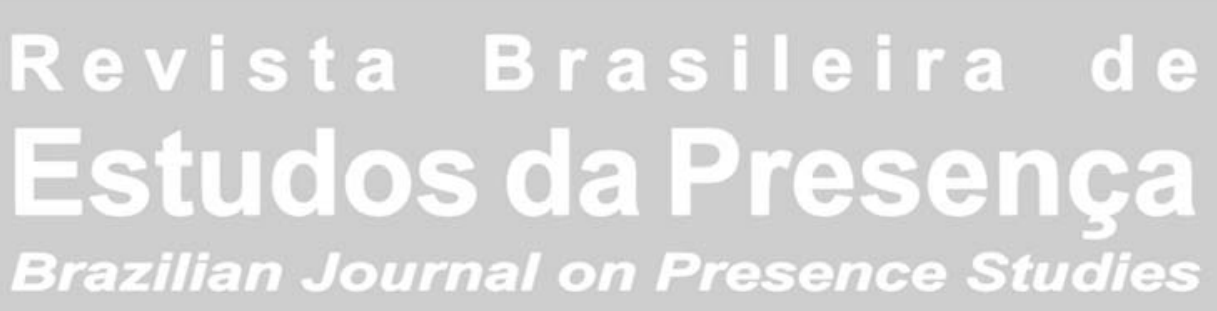

E-ISSN 2237-2660

motivadas por diferentes interesses, procurando tirar partido do potencial da RA como ferramenta para a veiculaçáo da informaçáo. Para tanto, a tecnologia deve adequar-se e expandir-se a partir da proposta conceitual que norteia o processo de criação, a vitalidade e a força do trabalho.

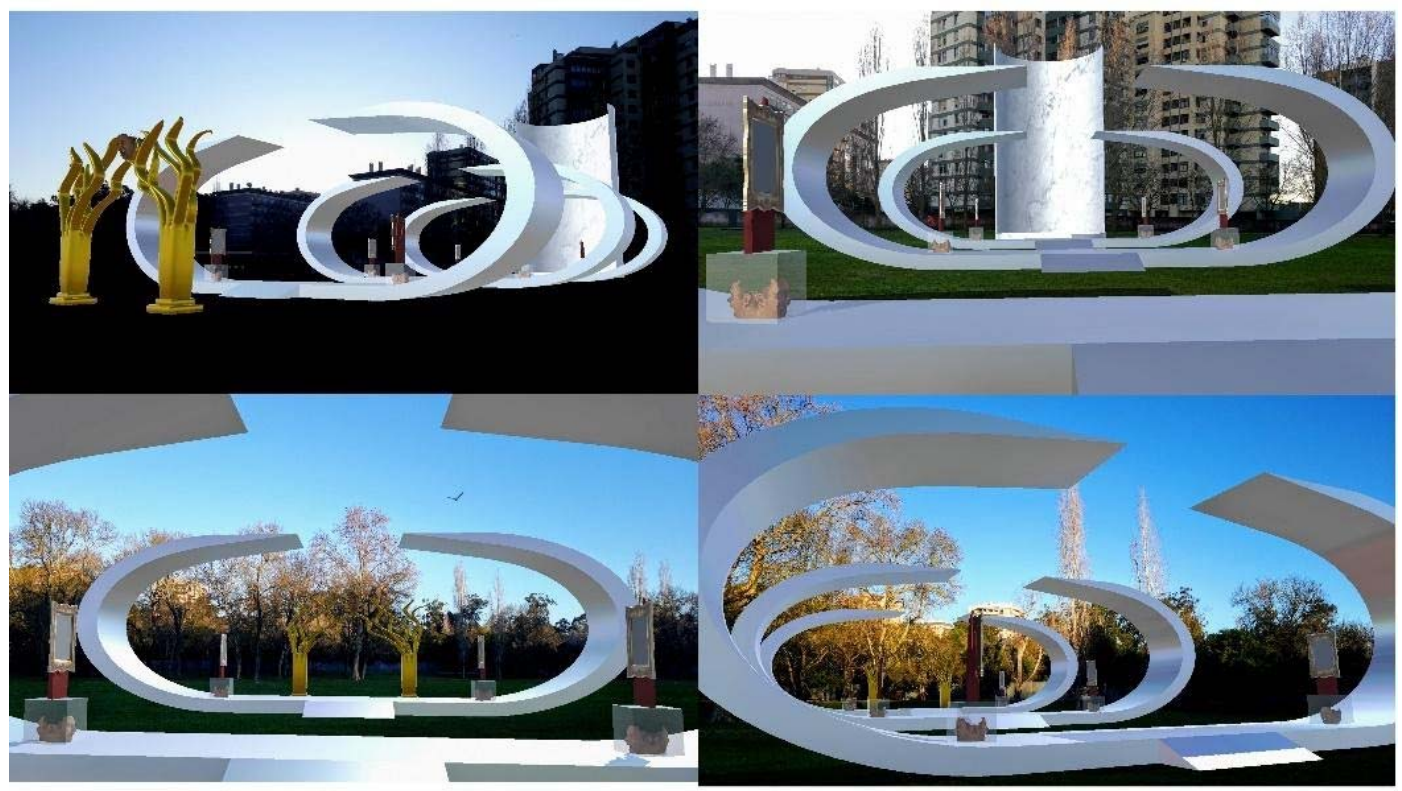

Figura 12 - Santuário (teste do aplicativo). Fonte: Arquivos do autor (2020).

\section{O Estar Presente em um Espaço Ausente}

A linguagem da performance possui a liberdade e a flexibilidade para estabelecer relaçóes voláteis entre o corpo e o espaço, permitindo que a percepção dos conteúdos tangíveis do território ocupado pela ação performática seja deslocada para um novo território sígnico. Tal ato é responsável por desencadear uma ruptura nas fronteiras que definem o aspecto simbólico e o uso cotidiano atribuído ao espaço ocupado, gerando entre os que habitam ou utilizam o território invadido os sentimentos de estranhamento e incerteza, pois, como afirma Carreira (2008, p. 69) “[...] a tomada de espaços da cidade por intervenções artísticas sempre implica na criação de 'estados de ruptura do cotidiano"”.

A presença da performance em um território, por si só, já apresenta a força necessária para iniciar uma interferência no cotidiano de um determinado espaço, a exemplo da primeira intervenção do peregrino realizada na Praça do Comércio em Lisboa. Contudo, o caminhar do peregrino por um 
território híbrido permite ir além da interferência no cotidiano, reanimando o espaço e redefinindo as suas formas e símbolos. A hibridização torna-se possível pela imaterialidade das estruturas digitais instaladas no espaço através da RA - um território cuja arquitetura é forjada pela aglutinação entre o concreto e o pixel. É o performer o elemento aglutinador da estrutura concretodigital desse território híbrido. Cabe à sua açáo revelar a presença dos conteúdos digitais que habitam o território, até então invisíveis, e evocar o uso dos ecrâs pelo público, como lentes que permitam o vislumbre de uma paisagem em transformação. Ao situar-se em um espaço em transformação, o corpo do peregrino transpóe a fronteira entre o tangível e o digital e os une. A ação performática recorre aos símbolos presentes no espaço digital para fixá-los em solo firme, no espaço tangível, estabelecendo entre estes a relaçáo necessária para a criação de um novo espaço simbólico, com camadas de informação que podem evocar ao ativismo político, social e ambiental.

O espaço performático, cujo conceito é ligado à ideia de cenografia dentro do campo das artes visuais, e não no campo da decoraçáo ou comunicaçáo, existe em relaçáo à noção de imagem e de movimento. As imagens são articuladas com as açôes e ativadas em cena. A cenografia ganha significado na sua integração ou justaposição com os outros elementos, ela não se conclui por si, como acontece na instalação, que se realiza a partir do momento em que ela é vista por alguém (Linke, 2006, p. 137).

Com a articulação entre a RA e a ação performática, diferentes conteúdos digitais podem ser inseridos em um espaço. $\mathrm{O}$ território ausente, de existência virtualizada, uma vez aglutinado ao espaço tangível por meio da RA em dispositivos móveis, permite a construção de um novo território, cujas estruturas e superfícies revelam novas cargas simbólicas e propiciam novas relaçôes do corpo com o espaço (Figura 13). Da mesma maneira, a virtualidade dos conteúdos digitais georreferenciados no espaço público possibilita à ação performática a manifestação do ativismo através da inserção de informaçóes que permanecerão mesmo após a sua realizaçáo, bastando apenas o acionamento do aplicativo para que estas sejam visualizadas. Assim, ao propor a hibridizaçáo do espaço público mediante a articulaçáo entre o tangível e o digital, solidificando terrenos para a ação performática em RA para dispositivos móveis, a investigaçáo Inter Faces se insere no conjunto de trabalhos exploratórios que enxergam na RA um campo em expansão para o processo de criação artístico. 
Ao incorporar a RA ao processo de criação, a investigação Inter Faces utilizou como referência trabalhos artísticos pioneiros no emprego dessa tecnologia com o fito de expandir as possibilidades poéticas até então exploradas, contribuindo com novas experiências. A análise comparativa dos processos de criaçáo dos trabalhos artísticos body (2008) e Parade to Hope (2011) permitiu a adoção de estratégias que viabilizassem a inserção de conteúdos digitais no espaço público, atuando como recursos para a ressimbolização ativista em diálogo constante com a açáo performática. Tal empresa implicou em desafios técnicos e conceituais, exigindo em sua etapa inicial de desenvolvimento a mudança do uso artístico previsto para a tecnologia da RA. Os registros fotográfico, videográfico e descritivo do processo de criação da ação performática Inter Faces, produzidos durante as etapas já concluídas e com ênfase nos desafios enfrentados e nas soluçóes encontradas, constituem material de referência para as próximas etapas e de consulta para o desenvolvimento de futuros processos de criaçáo que recorram ao uso poético da RA, já que tais documentos foram publicizados no site do projeto na internet e em plataformas de redes sociais.

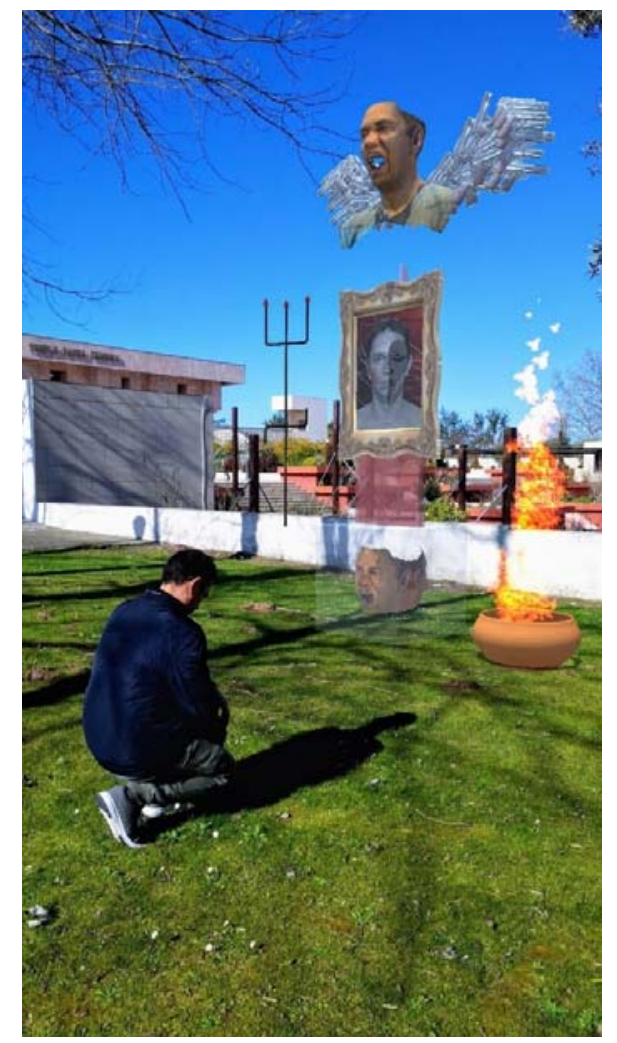

Figura 13 - Registro do teste da inserção de conteúdo digital em RA em espaço público. Fonte: Arquivos do autor (2019). 
Inter Faces, dessa forma, insere-se no âmbito dos debates sobre o uso da RA nos processos de criaçáo, especialmente no campo artístico, apresentando como contributo a possibilidade de articulaçáo dos conteúdos digitais visualizados em dispositivos móveis com o corpo performático e com o espaço público. Paralelamente, retoma a abordagem ativista atribuída a esta ferramenta por Skwarek (2014), expandindo-a ao correlacioná-la com a ação performática. As questôes intrínsecas à RA, como o seu crescimento promissor, acompanhado e impulsionado pela expansão da rede $5 \mathrm{G}^{18}$, da inteligência artificial e dos wearables ${ }^{19}$, que prevê o desenvolvimento de várias funcionalidades e a sua atuação nos mais diferentes setores, insere Inter Faces em outro debate que discute a futura massificação e incorporação da tecnologia da RA ao cotidiano. Isso não isenta a investigaçáo de adotar uma postura crítica sobre o uso da RA, pois, ao subverter as funcionalidades da tecnologia para a obtençáa de um produto artístico, o processo de criaçáo instrumentaliza o artista com as lentes capazes de revelar as demais proficuidades que a RA pode apresentar. Nesse aspecto, o terreno híbrido formado pelo tangenciamento do virtual sobre o real, cujo acesso é possibilitado pela RA, que insufla no personagem do peregrino a força necessária para a sua existência e para o seu caminhar, pode ser plano e firme ou irregular e lamacento. $\mathrm{O}$ tempo e o avançar da caminhada revelarão as paisagens vindouras, emanadas do crescente entrelaçamento entre o real e o digital.

\section{Notas}

1 Disponível em: <https://peregrinodigigal.home.blog/>. Acesso em: $12 \mathrm{dez}$. 2019. Blog criado para o registro das etapas dos processos de criaçáo da investigação Inter Faces.

2 Como no trabalho de recriaçáo em RV da obra de Van Gogh Starry Night realizado por George Peaslee. Disponível em: <https://www.youtube.com/watch?v=Woc0GZkDa7k>. Acesso em: 12 dez. 2019.

3 Técnica de animação que consiste no registro fotográfico ou no desenho realizado quadro a quadro, com o objetivo de simular o movimento.

4 Disponível em: <http://stelarc.org/projects.php>. Acesso em: 11 dez. 2019.

5 Disponível em: <https://www.ekac.org>. Acesso em: 12 dez. 2019. 
6 Marcadores são imagens impressas, com alto teor de contraste, que são detectados pelo dispositivo de RA, utilizados para o posicionamento e visualização dos conteúdos sobrepostos às imagens da cena real.

7 Disponível em: <http://www.artoolkitx.org>. Acesso em: 12 dez. 2019.

Copyleft indica o livre direito de cópia. O seu desenho corresponde ao símbolo do copyright invertido.

9 iOS é o sistema operacional móvel da Apple Inc. desenvolvido em 2007. Android é o sistema operacional móvel desenvolvido pelo consórcio Open Handset Alliance, tendo o grupo Google como principal colaborador.

10 Software desenvolvido pela Unity Technologies (https://unity.com). É utilizado como motor para a criação de jogos e aplicativos.

11 Disponível em: <https:/www.ptc.com/en/products/augmented-reality/vuforia>. Acesso em: $12 \mathrm{dez} .2019$.

12 Disponível em: <http://aec.belasartes.ulisboa.pt/> e <http://ars.electronica.art/outofthebox/en/timelessness/>. Acesso em: 12 dez. 2019.

13 Personagem do Bumba-meu-Boi do Maranhão. A sua presença é frequente no sotaque de zabumba e a sua figura simboliza os espíritos das matas.

14 Disponível em: <https://www.facebook.com/O-Peregrino-Digital-101578641277523> e <https://peregrinodigigal.home.blog/>. Acesso em: 11 dez. 2019.

15 Inauguração em 21 de novembro de 2019, na Galeria da Cisterna da FBAUL <http://www.belasartes.ulisboa.pt/inshadow-2019-screendance-festival/>. Acesso em: 12 dez. 2019.

16 Divindade cultuada pelo Candomblé. Possui a função de estabelecer a comunicação entre os demais orixás e a humanidade.

17 Até a conclusão do presente artigo, a última etapa da performance não havia sido apresentada publicamente, tendo a sua realização prevista para o segundo semestre de 2020.

$185^{\mathrm{a}}$ geração de rede móvel para a transmissão de dados. A velocidade prevista para esta rede é de 10Gbps, aumentando significativamente a velocidade da banda larga e diminuindo o tempo de latência.

19 Wearables é o termo em inglês para tecnologias vestíveis. Correspondem a gadgets que possuem conectividade com outros dispositivos e podem ser utilizados 
como itens de vestuário. Os exemplos mais comuns correspondem aos relógios inteligentes (smartwatches).

\section{Referências}

ALMEIDA, Hugo Picado de. A Sociedade dos Ecrãs: Entre Ver e Ser Visto. 2012. Dissertação (Mestrado em Ciências da Comunicação) - Universidade Católica Portuguesa, Lisboa, 2012.

CANDY, Linda; EDMONDS, Ernest. Practice-Based Research in the Creative Arts: Foundations and Futures from the Front Line. Leonardo, United States, v. 51, n. 1, p. 63-69, 2018. Disponível em: <https://www.mitpressjournals. org/doi/pdf/10.1162/LEON_a_01471>. Acesso em: 19 maio 2020.

CARREIRA, André. Teatro de invasão: redefinindo a ordem da cidade. In: LIMA, Evelyn Furquim Werneck (Org.). Espaço e teatro: do edifício teatral à cidade como palco. Rio de Janeiro: Sete Letras; FAPERJ, 2008. P. 67-78.

CRAIG, Alan B. Understanding Augmented Reality: concepts and applications. Waltham, MA: Morgan Kaufmann, 2013.

DOMINGUES, Diana (Org.). A arte no século XXI: a humanização das tecnologias. São Paulo: Fundação da UNESP, 1997.

DOMINGUES, Diana; VENTURELLI, Suzete. Cibercomunicação cíbrida no continuum virtualidade aumentada e realidade aumentada - era uma vez ... a realidade. Revista ARS, São Paulo, ECA-USP, v. 5, n. 10, p. 109-121, jan. 2007.

FERREIRA, André Luiz Rodrigues. Uma Intervenção Urbana Performativa: deslocamentos de um bufão. Revista Brasileira de Estudos da Presença, Porto Alegre, Universidade Federal do Rio Grande do Sul, v. 9, n. 2, p. 1-22, abr./jun. 2019.

GRAU, Oliver. Arte virtual: da ilusão à imersão. Tradução de Cristina Pescador. São Paulo: Editora SENAC, 2007.

HAMDAN, Camila Cavalheiro. CORPOS TATUADOS: Experiências Sensíveis em Realidade Aumentada Móvel. 2015. Tese (Doutorado em Arte) - PósGraduação em Arte, Universidade de Brasília, Brasília, 2015.

HANNINGTON, Bella; MARTIN, Bruce. Universal Methods of Design: 100 Ways to Research Complex Problems, Develop Innovative Ideas, and Design Effective Solutions. Beverly: Rockport Publishers, 2012. 
JERALD, Jason. The Vr Book: Human-Centered Design for Virtual Reality. New York: ACM Books \#8, 2016.

LINKE, Ines. O Espaço Performático. Artefilosofia, Ouro Preto, n. 1, p. 134138, jul. 2006.

MACHADO, Vanda. Exu: o senhor dos caminhos e das alegrias. In: ENCONTRO DE ESTUDOS MULTIDISCIPLINARES EM CULTURA, 6., 2010, Salvador. Anais... Salvador: UFBA, 2010. Disponível em: <http://www.cult.ufba. br/wordpress/24929.pdf>. Acesso em: 13 dez. 2019.

MILGRAM, Paul; KISHINO, Fumio. A Taxonomy of Mixed Reality Visual Displays. IEICE Transactions on Information Systems, v. E77-D, n. 12, Dec. 1994.

PRESSMAN, Roger S. Engenharia de Software. 7. ed. Rio de Janeiro: McGrawHill, 2011.

RAPOSO, Paulo. Artivismo: articulando dissidências, criando insurgências. Cadernos de Arte e Antropologia, Lisboa, v. 4, n. 2, 2015. Disponível em: <http://journals.openedition.org/cadernosaa/909>. Acesso em: 15 jan. 2020.

SANTOS, Maria Luisa Duarte da Silva. A Criaçáo Artística e o Processo Criativo: uma abordagem estético-plástica e psico-cognitiva. 2004. Dissertação (Mestrado em Teorias da Arte) - Universidade de Lisboa, Lisboa, 2004.

SKWAREK, Mark. Augmented Reality Activism. In: GEROIMENKO, Vladimir (Ed.). Augmented Reality Art: From an Emerging Technology to a Novel Creative Medium. Heidelberg: Springer, 2014. P. 3-32.

Régis Costa de Oliveira é doutorando em Artes pela Faculdade de Belas-Artes da Universidade de Lisboa, Mestre em Artes pela Universidade Federal do Maranhão. Professor de Artes Visuais do Instituto Federal de Educação, Ciência e Tecnologia do Maranhão

ORCID: http://orcid.org/0000-0003-2373-2637

E-mail: regis.oliveira@ifma.edu.br

Mónica Mendes é professora auxiliar no curso de Artes Multimédia da Faculdade de Belas-Artes da Universidade de Lisboa e pesquisadora em Artes Digitais no ITI/LARSyS. É doutora em Digital Media e sua investigaçáo situa-se na interseção das artes, tecnologias e sustentabilidade ambiental.

ORCID: http://orcid.org/0000-0001-6826-9549

E-mail: m.mendes@belasartes.ulisboa.pt 
Anselmo Cardoso de Paiva é professor associado do Departamento de Ciência da Computação da Universidade do Maranhão, Brasil. Ele obteve um doutorado na PUC-Rio, Brasil, em 2001. Seus interesses de pesquisa incluem computação gráfica, sistemas de informação geográfica, sistema de imagens médicas e sistemas de informação.

ORCID: http://orcid.org/0000-0003-4921-0626

E-mail:paiva@nca.ufma.br

Este texto inédito também se encontra publicado em inglês neste número do periódico.

Recebido em 27 de janeiro de 2020 Aceito em 01 de junho de 2020

Editor-responsável: Gilberto Icle

Este é um artigo de acesso aberto distribuído sob os termos de uma Licença Creative Commons Atribuição 4.0 Internacional. Disponível em: <http://creative commons.org/licenses/by/4.0>. 